\title{
Perfil da expressão gênica de larvas de Tetrapedia diversipes (Hymenoptera: Apidae) em diapausa
}

\section{Priscila Karla Ferreira dos Santos}

São Paulo 2015

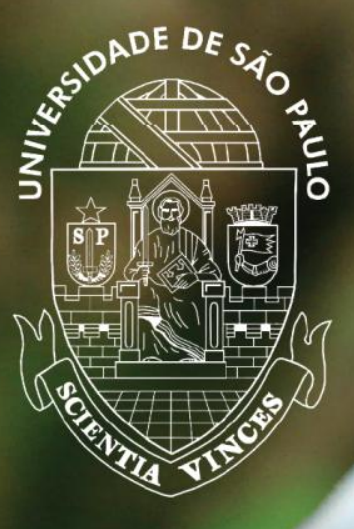


Capa: Tetrapedia diversipes. Foto tirada em set/2007 na Estação Biológica de Boracéia, Salesópolis, São Paulo, por Guaraci Duran Cordeiro. 
Priscila Karla Ferreira dos Santos

Perfil da expressão gênica de larvas de Tetrapedia diversipes (Hymenoptera: Apidae) em diapausa

Gene expression profile of diapause larvae of Tetrapedia diversipes (Hymenoptera: Apidae) 

Priscila Karla Ferreira dos Santos

Perfil da expressão gênica de larvas de Tetrapedia diversipes

(Hymenoptera: Apidae) em diapausa

Gene expression profile of diapause larvae of Tetrapedia

diversipes (Hymenoptera: Apidae)

Dissertação apresentada ao Instituto de Biociências da Universidade de São Paulo, para a obtenção de Título de Mestre em Ciências, na Área de Biologia/Genética.

Orientadora: Dra. Maria Cristina Arias 



\section{Ficha catalográfica}

Ferreira-Santos, Priscila Karla

Perfil da expressão gênica de larvas de Tetrapedia diversipes (Hymenoptera: Apidae) em diapausa

Número de páginas: 81

Dissertação (Mestrado) - Instituto de Biociências da Universidade de São Paulo. Departamento de Genética e Biologia Evolutiva.

1. Expressão gênica 2. Abelha I. Universidade de São Paulo. Instituto de Biociências. Departamento de Genética e Biologia Evolutiva.

\section{Comissão julgadora:}

Prof(a). Dr(a).

Prof(a). Dr(a).

Profa. Dra. Maria Cristina Arias

Orientadora 

Aos meus pais e irmão 

"Happiness only real when shared" Christopher McCandless 



\section{AGRADECIMENTOS}

Agradeço primeiramente à minha orientadora Dra. Maria Cristina Arias por ter aceitado me orientar no mestrado e por confiar em mim para desenvolver este projeto, pela agradável convivência no ambiente de trabalho e por todo apoio e contribuição durante esses três anos.

Aos colegas do Laboratório de Genética e Evolução de Abelhas, especialmente à Natália que teve enorme contribuição para o desenvolvimento do projeto e à Elaine que tem sido essencial na minha formação como pesquisadora (que está apenas começando). Agradeço também à Susy por toda ajuda no laboratório.

Agradeço aos meus amigos de república, que são minha família em São Paulo. Especialmente novamente à Elaine e ao Heman por todas as discussões e contribuições ao trabalho fora do ambiente acadêmico e principalmente à Carol por tolerar todas as conversas sobre evolução, abelhas, biologia molecular, plantas etc.

Agradeço aos meus pais e meu irmão pela apoio financeiro e moral para seguir esta jornada que escolhi.

Aos colegas do Laboratório de Abelhas - IB-USP pelos indivíduos de $T$. diversipes e por serem sempre muito solícitos quando precisamos de algo. Ao Dr. Artur Gruber pelos conselhos. Ao apoio financeiro do Núcleo de Apoio à Pesquisa (NAP), da Fundação de Apoio à Pesquisa do Estado de São Paulo (FAPESP) e à Coordenação de Aperfeiçoamento de Pessoal de Nível Superior (CAPES) pela bolsa de Mestrado 



\section{ÍNDICE}

Resumo

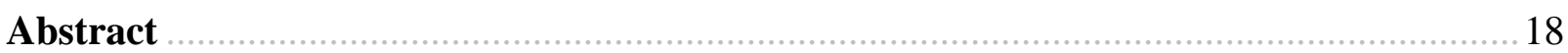

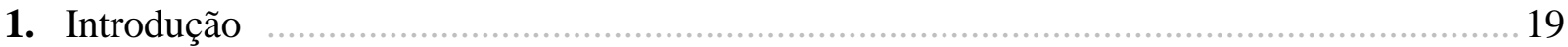

1.1 A diapausa nos Insetos ……

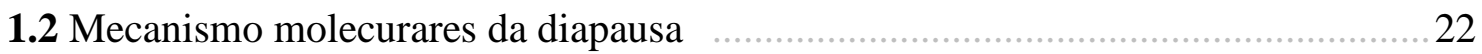

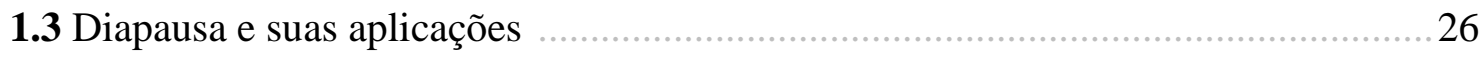

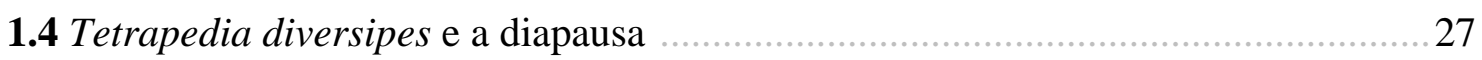

2. Objetivos

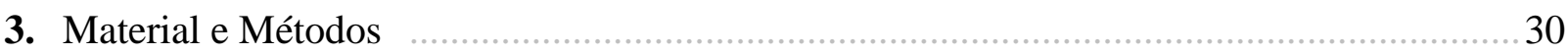

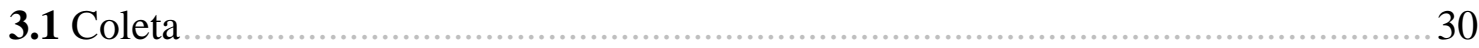

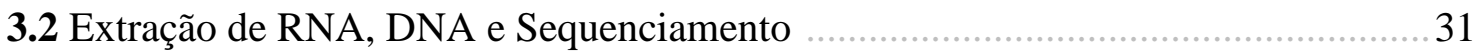

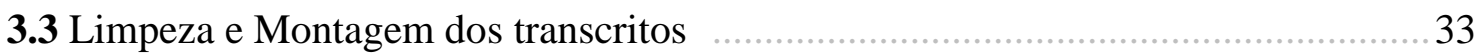

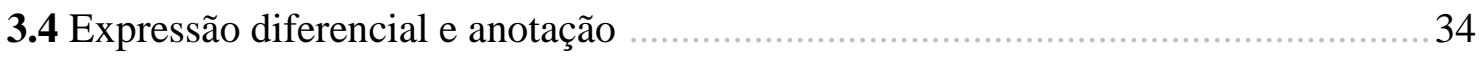

4. Resultados

4.1 Limpeza, montagem e anotação do transcriptoma das larvas de $T$.

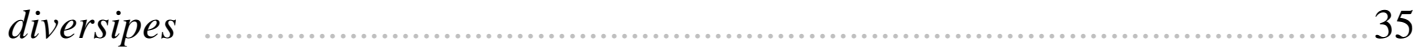

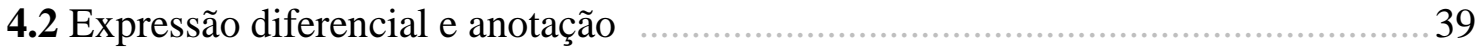

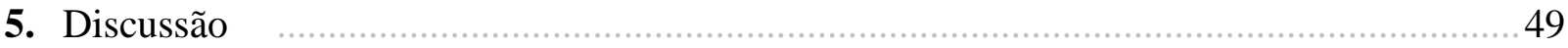

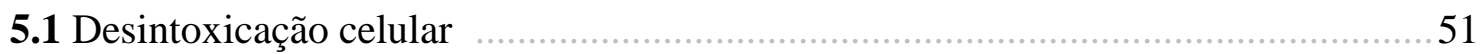

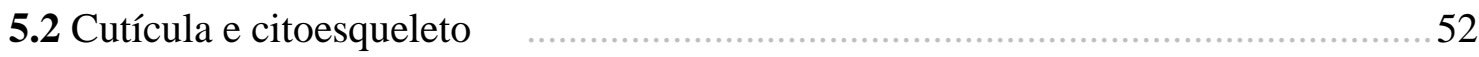

5.3 Metabolismo de lipídeos e esteróis . .......................................................... 54

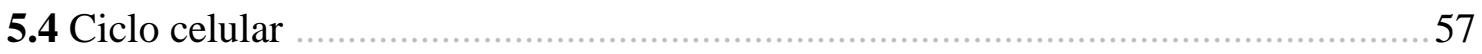

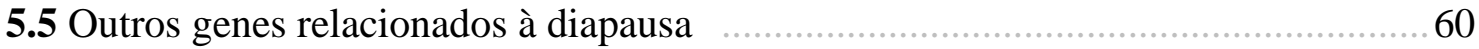

6. Conclusão

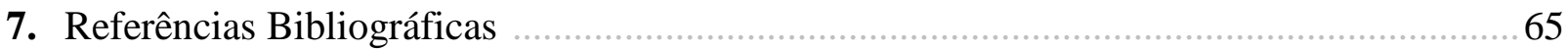

APÊNDICE A

APÊNDICE B 



\section{RESUMO}

A diapausa é um fenômeno amplamente presente nos artrópodes e é considerada como primordial para o sucesso evolutivo da Classe Insecta, pois possibilita a sobrevivência em condições adversas, como estações frias e secas. Sabe-se que durante a diapausa ocorre o silenciamento de muitos genes e que outros são unicamente expressos nesta fase. Embora existam evidências de que o processo da diapausa tenha se mantido conservado durante a evolução das espécies, ainda há lacunas no conhecimento sobre o nível de conservação dos padrões metabólicos. Um bom modelo para se estudar a diapausa é Tetrapedia diversipes, uma espécie bivoltina de abelha solitária. Os indivíduos que nascem na primeira geração seguem o desenvolvimento desde ovo até adulto em tempo bem menor do que aqueles que nascem na segunda geração; estes retardam o desenvolvimento na fase larval. Além disso, essa espécie é de fácil obtenção no seu ambiente natural, pois apresenta alta taxa de nidificação em ninhos-armadilha. O objetivo deste trabalho foi comparar o perfil de expressão de genes entre as larvas da $1^{\text {a }}$ geração (que não entram em diapausa), larvas da $2^{a}$ geração (que entrariam em diapausa) e das larvas em diapausa. Foram identificados 196 genes diferencialmente expressos, destes 87 foram anotados. Muitos destes genes já foram descritos na literatura como relacionados à diapausa em outras espécies, no entanto, o padrão de expressão não é conservado. Os genes aqui identificados foram divididos em cinco grupos: relacionados à desintoxicação celular, cutícula e citoesqueleto, metabolismo de lipídeos e esteróis, ciclo celular e outros genes relacionados à diapausa. 


\begin{abstract}
The diapause is broadly distributed among the arthropods and has had an important role for the evolutionary success of the Class Insecta, mainly because this process permits insects to explore adverse conditions, such as cold and dry seasons. It is known that there are many genes being silenced and others being uniquely expressed during diapause. And although there are evidences that the diapause process has remained conserved during the evolution of species, it is still not clear how conserved are the metabolic patterns involved in this behavior. Tetrapedia diversipes is a solitary bee and a good model to study diapause. Individuals from the first generation do not enter in diapause and develop faster than individuals from the second generation, which enter in diapause during the winter. Moreover, this species is easy to capture in natural conditions due to the high rate of nesting in trap nests. The aim of this work was to compare the gene expression profile among non-diapause larvae from first and second generation (about to enter diapause) and larvae already in diapause, trough transcriptome data. One hundred ninety-four genes were identified as differentially expressed and 87 of them were annotated. Many of these genes have already been described as related to diapause in others species, but the expression pattern was not conserved. These genes were divided in five groups: related to cellular detoxification, cuticle and cytoskeleton, lipids and steroids metabolism, cell cycle and other genes related to diapause.
\end{abstract}




\section{Introdução}

\subsection{A diapausa nos Insetos}

Dormência é um termo genérico para o estado de supressão do desenvolvimento, e pode ser classificada em dois tipos: (1) quiescência que é uma resposta imediata a um fator ambiental limitante; e (2) diapausa que é uma via alternativa ao desenvolvimento direto, seu começo geralmente antecede uma condição adversa e o final não necessariamente coincide com o fim da adversidade. O estado de dormência é adaptativo e geralmente acompanhado por redução no metabolismo (Kostál 2006).

O termo diapausa se refere a alterações fisiológicas e comportamentais nos organismos (Fielenbach \& Antebi 2008), podendo compreender: (1) parada no desenvolvimento ativo; (2) dormência reprodutiva; (3) redução na taxa de metabolismo; ou (4) a combinação de todos (Emerson et al. 2009). Essas alterações ocorrem em resposta a estímulos ambientais que anunciam mudanças sazonais, tais como: restrição alimentar, estresse, mudanças no fotoperíodo ou temperatura (Tauber et al. 1986).

A diapausa é um fenômeno amplamente presente nos artrópodes e possibilita que esses organismos sobrevivam durante estações frias e secas. Este processo é considerado como um fator importante para o sucesso evolutivo da Classe Insecta (Denlinger 2002).

Nos insetos a diapausa pode ocorrer nas diversas fases do ciclo de vida: embrião, larva, pupa, adulto farato e adulto (Denlinger 2002). Nos estágios iniciais do ciclo de vida ela é denominada de "diapausa do desenvolvimento" e no adulto de "diapausa reprodutiva" (Wolschin \& Gadau 2009). No entanto, em uma mesma espécie, ela é restrita a um desses estágios (Denlinger 2002).

Kostál (2006) divide a diapausa em três fases eco-fisiológicas: pré-diapausa, diapausa e pós-diapausa. Cada fase é regulada pela interação entre fatores endógenos e exógenos. 
Pré-diapausa: nesta fase os indivíduos ainda estão em desenvolvimento, mas em resposta a um estímulo do ambiente eles se tornam destinados a entrar em diapausa. O estímulo que induz a diapausa é percebido durante um período específico de sensibilidade que é determinado geneticamente (Kostál 2006).

A variação no fotoperíodo é o estímulo natural melhor compreendido (Kostál 2006). É um marcador sazonal em zonas temperadas, mas de efeito reduzido nos trópicos (Denlinger 1986). Os padrões de temperatura, chuva e fotoperíodo descritos para a área tropical não são forças limitantes, comparáveis ao inverno nas zonas temperadas, para retardar o desenvolvimento de insetos. Na região tropical mudanças na qualidade do alimento podem servir como um estímulo para indução da diapausa (Denlinger 1986).

As mudanças no fotoperíodo têm sido relacionadas com a diapausa em diferentes espécies de Lepidoptera (Xia et al. 2012; Wang et al. 2012; Lu et al. 2013; Zhang et al. 2013) e Diptera (Emerson et al. 2010; Poelchau et al. 2011; Vesala et al. 2012; Meuti et al. 2015). Por outro lado, para espécies de abelhas como Osmia bicornis (Hymenoptera) o fotoperíodo não parece ser o estímulo envolvido no início da diapausa, pois o desenvolvimento dos indivíduos (da fase de ovo até a fase adulta) ocorre em um ninho selado e em completa escuridão (Wasielewski et al. 2013), mesma situação de desenvolvimento que os indivíduos de Tetrapedia diversipes (Hymenoptera) (Alves-dosSantos et al. 2002).

Nesta fase de pré-diapausa, pode ocorrer o sequestro de reservas adicionais de gordura, deposição de camadas extras de hidrocarbonetos para impermeabilização da cutícula ou a síntese de proteínas que permanecem presentes na hemolinfa durante a diapausa (Denlinger 2002). Esta fase é de intensa alimentação e acúmulo de reservas (Kostál 2006). 
Os indivíduos que entram ou não em diapausa estocam reservas dos mesmos grupos: lipídeos, carboidratos, aminoácidos, vitaminas e minerais. Mas na fase de prédiapausa os triacilgliceróis são a principal reserva estocada, geralmente constituem de 8095\% do conteúdo total de lipídeos (Hahn \& Denlinger 2011). A composição de ácidos graxos dos triacilgliceróis pode então diferir qualitativa e quantitativamente entre os indivíduos que entrarão ou não em diapausa, e esta composição é altamente influenciada pela composição de ácidos graxos na dieta do inseto. Os indivíduos que entram em diapausa contêm uma reserva com mais ácidos graxos insaturados, enquanto indivíduos que não entram possuem mais ácidos graxos saturados (Hahn \& Denlinger 2011).

As reservas de glicogênio são convertidas em glicose e trealose, que são transportadas para os tecidos e servem como combustíveis para o catabolismo, elas também são metabolizadas para produzir moléculas crioprotetoras que têm como base açúcares ou álcool derivado do açúcar. Glicerol e sorbitol são as moléculas crioprotetoras mais comuns nos insetos (revisto por Hahn \& Denlinger, 2011).

Todos estes eventos que ocorrem durante a pré-diapausa refletem no padrão de expressão de genes específicos relacionados à diapausa (Denlinger 2002).

Diapausa: esta fase se inicia quando o desenvolvimento direto cessa seguido pela supressão metabólica. Mas, em larvas de vida livre e adultos, que podem se mover, a supressão metabólica é menos profunda e os indivíduos podem continuar ingerindo alimento e estocando energia durante este período (Kostál 2006). O início da diapausa pode ocorrer em diferentes períodos do ano e em diferentes indivíduos de uma mesma população, então cada indivíduo mantém a diapausa por tempo diferente. Mudanças específicas no ambiente estimula a diminuição na intensidade da diapausa e sincroniza os indivíduos de uma mesma população. No fim desta fase, é restabelecido o estado fisiológico em que o desenvolvimento direto pode ser retomado (Kostál 2006). 
Pós-diapausa: embora as condições biológicas para o desenvolvimento direto já estejam restabelecidas, as condições ambientais ainda não. Sendo assim, os indivíduos permanecem em um estado de quiescência (Kostál 2006). Os insetos nesta fase parecem fisiologicamente idênticos aos indivíduos em diapausa, eles não apresentam mudanças perceptíveis no desenvolvimento, no entanto, a expressão gênica entre estas duas fases é distinta (Denlinger 2002; Poelchau et al. 2013c; Yocum et al. 2015).

\subsection{Mecanismos moleculares da diapausa}

O início e a progressão da diapausa são mediados por mecanismos moleculares como: diferença na expressão de genes, eventos pós-transcricionais, modificações póstraducionais das proteínas e localização de proteínas em regiões específicas dentro das células. Identificar as mudanças nesse processo, a sua conservação evolutiva e o seu compartilhamento entre os organismos são questões centrais nos estudos sobre diapausa (MacRae 2010).

Sabe-se que durante este período não há apenas o silenciamento de genes. Alguns são unicamente expressos nesta fase, outros são expressos apenas na fase inicial ou na fase tardia, e outros são expressos com interrupções durante a diapausa. Estas diferenças refletem a complexidade e dinamismo desta fase do desenvolvimento (Denlinger 2002).

Vários mecanismos endócrinos regulam a diapausa, mas precisamente qual hormônio está envolvido depende da espécie e do estágio do desenvolvimento em que ela ocorre. Em Bombyx mori (Lepidoptera) a diapausa embrionária é induzida pela ação do hormônio da diapausa (um neuropeptídeo liberado do gânglio subesofágico da fêmea parental) e é mantida pela elevada quantidade de ecdisteroides (revisado por Denlinger, 2002). O mesmo acontece durante a diapausa da larva farato de primeiro ínstar em Lymantria dispar (Lepidoptera), enquanto há uma alta concentração de ecdisteroides, a 
diapausa persiste e uma redução destes hormônios é necessária para o término da diapausa (Denlinger \& Lee 1997).

A função central de ecdisteroides na diapausa de larvas e pupas sugere que os genes associados a esses hormônios podem ser críticos na regulação desse processo. Ao contrário da diapausa no embrião, durante as fases de larva e pupa, há uma falha da glândula protorácica em sintetizar ecdisteroides necessários para promover o desenvolvimento (Denlinger 2002). A falha na glândula protorácica em liberar ecdisona (um hormônio esteroide) impede que a larva passe pelo processo de muda para o próximo ínstar, permanecendo no estágio de diapausa (Denlinger \& Armbruster 2014).

A maioria dos casos de diapausa no adulto pode ser atribuída à ausência de hormônio juvenil (HJ). O HJ é produzido pela corpora allata (glândula endócrina) dos insetos e atua juntamente com ecdisteroides na regulação da muda, metamorfose e reprodução nos insetos (Denlinger \& Armbruster 2014). O bloqueio da produção deste hormônio resulta na interrupção da maturação dos ovos, em glândulas acessórias atrofiadas, na degeneração dos músculos de voo e na parada da atividade de acasalamento. A ativação dessa glândula ocorre no término da diapausa (Denlinger 2002).

Em alguns casos há evidência de efeito materno na regulação da diapausa. A parada do desenvolvimento na fase embrionária é a forma mais comum (Denlinger 1998). Em B. mori, anteriormente mencionado, a diapausa do embrião é determinada pela liberação de hormônio da diapausa pela mãe. Outros efeitos maternos são menos diretos e podem determinar a capacidade da larva ou da pupa da próxima geração entrar em diapausa, como acontece em algumas espécies de Hymenoptera e Diptera (revisado por Denlinger, 2002). As sinalizações hormonais, que ocorrem nos diferentes tipos de 
diapausa, são responsáveis pelos padrões de expressão gênica únicos observados durante esse processo (Denlinger 2002).

As proteínas heat shock (HSPs) estão envolvidas com os diferentes tipos de diapausa, desde a dormência de bactérias e fungos à hibernação de mamíferos. Isso sugere que há mecanismos conservados que contribuem para a parada do desenvolvimento (Denlinger 2002). A função dessas proteínas ainda não está bem compreendida. Sabe-se que são chaperonas, cuja função é manter a integridade estrutural de proteínas durante a dormência ou contribuir com a parada do ciclo celular (Denlinger 2002). Devido à presença de HSPs nos diferentes tipos de diapausa, muitos estudos sobre expressão gênica focaram nestas proteínas (Rinehart et al. 2000; Yocum 2001; Denlinger 2002; Yocum et al. 2006, 2005; Tachibana et al. 2005; Robich et al. 2007; Wolschin \& Gadau 2009; Zhang \& Denlinger 2010; Aruda et al. 2011; Gong et al. 2013; Lu et al. 2013).

Embora estas proteínas estejam presentes em diferentes organismos, não há um padrão conservado na expressão dos genes que as codificam. Por exemplo, sabe-se que a expressão do gene da proteína heat shock HSP90 diminui durante a diapausa na pupa de Sarcophaga crassipalpis (Diptera) (Rinehart \& Denlinger 2000), na larva da vespa Nasonia vitripennis (Wolschin \& Gadau 2009) e na pupa de Helicoverpa zea (Lepidoptera) (Zhang \& Denlinger 2010), no entanto, verificou-se um aumento na sua expressão durante a diapausa da abelha solitária Megachile rotundata (Yocum et al. 2005) e na pupa de Delia antiqua (Diptera) (Chen et al. 2005). A expressão de Hsp70 foi alta durante a diapausa em S. crassipalpis (Rinehart et al. 2000), em M. rotundata (Yocum et al. 2005) e na diapausa reprodutiva de Leptinotarsa decemlineata (Coleoptera) (Yocum 2001), mas não houve alteração da expressão deste gene na diapausa do adulto em Culex pipiens (Diptera) (Rinehart et al. 2006), de Drosophila 
triauria (Goto et al. 1998), na larva de Lucilia sericata (Diptera) (Tachibana et al. 2005) e na pupa de H. zea (Zhang \& Denlinger 2010). O gene Hsp23 teve sua expressão aumentada em S. crassipalpis (Yocum et al. 1998) e em Calliphora vicina (Diptera) (Fremdt et al. 2014), mas não houve alteração em L. sericata (Tachibana et al. 2005).

Além das proteínas heat shock, a via de sinalização da insulina, mais conhecida por regular o metabolismo de carboidrato e gordura em mamíferos, é altamente conservada e uma candidata promissora como reguladora das reservas energéticas durante a diapausa dos insetos (Hahn \& Denlinger 2011). Mutações nesta via estão envolvidas com a formação da larva dauer (estágio em diapausa) de Caenorhabditis elegans (Rhabditida) (Kimura et al. 1997). A formação de larvas dauer ocorre quando há condições adversas induzindo a entrada em diapausa (Fielenbach \& Antebi 2008). Esta via também está envolvida com o controle da diapausa no adulto de $C$. pipiens (Sim \& Denlinger 2008).

Vários genes foram identificados como diferencialmente expressos em estudos de diapausa em diferentes grupos animais e estão envolvidos com o metabolismo energético (Ragland et al. 2010; Bao \& Xu 2011; Pavlides et al. 2011), metabolismo de lipídeos (Ragland et al. 2010; Bao \& Xu 2011; Reynolds et al. 2012; Poelchau et al. 2013b; 2013c), resposta ao estresse (Robich et al. 2007; Bao \& Xu 2011; Poelchau et al. 2011, 2013a; Zhang et al. 2013), vias de sinalização (Bao \& Xu 2011; Yocum et al. 2015), citoesqueleto (Kim et al. 2006; Robich et al. 2007; Emerson et al. 2010; Bryon et al. 2013), ciclo celular (Bao \& Xu 2011; Yocum et al. 2015), formação de cutícula (Emerson et al. 2010; Zhang et al. 2013; Poelchau et al. 2013b), metabolismo de hormônios (Bao \& Xu 2011; Poelchau et al. 2011, 2013c) e elementos transponíveis (Robich et al. 2007; Pavlides et al. 2011). 
Recentemente, em um estudo sobre a diapausa em Aedes albopictus (Diptera) utilizando sequenciamento de nova geração (RNA-Seq), o gene antígeno nuclear de proliferação celular (pcna) e o phosphoenolpyruvate carboxykinase (pepck) foram sugeridos como parte de um toolkit genético da diapausa entre diferentes espécies e estágios. Ambos encontraram-se super expressos na pré-diapausa em Ae. albopictus e já haviam sido relacionados com a diapausa em outros organismos (Poelchau et al. 2013b).

\subsection{Diapausa e suas aplicações}

Estudos sobre diapausa abordam tanto questões básicas sobre a adaptação dos organismos às heterogeneidades do ambiente, quanto questões mais aplicadas como antecipar respostas biológicas em relação ao contínuo aquecimento global (Poelchau et al. 2013c).

O entendimento detalhado do mecanismo da diapausa pode trazer inúmeras contribuições para: (1) identificação de biomarcadores, pois sabe-se que insetos em diapausa são mais resistentes aos pesticidas, portanto saber quando uma espécie entra em diapausa pode contribuir para a aplicação efetiva de pesticidas (Denlinger 2008); (2) manipulação do desenvolvimento de insetos polinizadores para obtenção de adultos na época das floradas de interesse econômico, por exemplo (Denlinger 2008): (3) desenvolvimento de drogas para bloquear transmissões de doenças virais, pois em insetos, durante esta fase, a replicação viral é interrompida, o que sugere a presença de um mecanismo molecular atuante (Denlinger 2008); (4) incrementar o conhecimento sobre o processo de envelhecimento, pois insetos em diapausa podem viver dez vezes mais que aqueles que não passam por esta fase (Denlinger 2008); (5) desenvolvimento de novos fármacos, pois muitos genes de defesa são altamente expressos durante a diapausa para evitar infecções. Os alloferons (peptídeos antimicrobianos), por exemplo, foram 
isolados da larva em diapausa de $C$. vicina e mostraram atividades antiviral e antitumoral em camundongos (Chernysh et al. 2002); (6) entender questões básicas relacionadas ao estoque e utilização de energia, pois muitos insetos acumulam gordura na pré-diapausa e entender como esta mudança fisiológica ocorre pode contribuir para a saúde humana (ex. obesidade e diabetes) (Hahn \& Denlinger 2011); e (7) desenvolvimento de estratégias de armazenamento de tecidos para transplantes de órgãos humanos, pois a capacidade de diminuir o metabolismo é uma característica impressionante que ocorre durante a diapausa (Hahn \& Denlinger 2011).

\subsection{Tetrapedia diversipes e a diapausa}

Os gêneros Tetrapedia e Coelioxoides compreendem abelhas solitárias e juntos compõem a tribo Tetrapediini (Michener 2007). As espécies T. diversipes (Figura 1) e Coelioxoides waltheriae já foram amplamente estudadas em relação ao desenvolvimento e comportamento de nidificação (Alves-dos-Santos et al. 2002). Naturalmente, $T$. diversipes nidifica em cavidades de troncos previamente utilizados por besouros, podendo também nidificar em ninhos-armadilha. Os ninhos consistem de células separadas umas das outras por uma camada de grãos finos de areia misturados a óleo, e uma massa de pólen misturada a óleo ocupando toda a célula, sendo o ovo colocado no alimento. $\mathrm{O}$ desenvolvimento de $T$. diversipes consiste de cinco ínstares larvais, pupa e adulto (Alves-dos-Santos et al. 2002). 


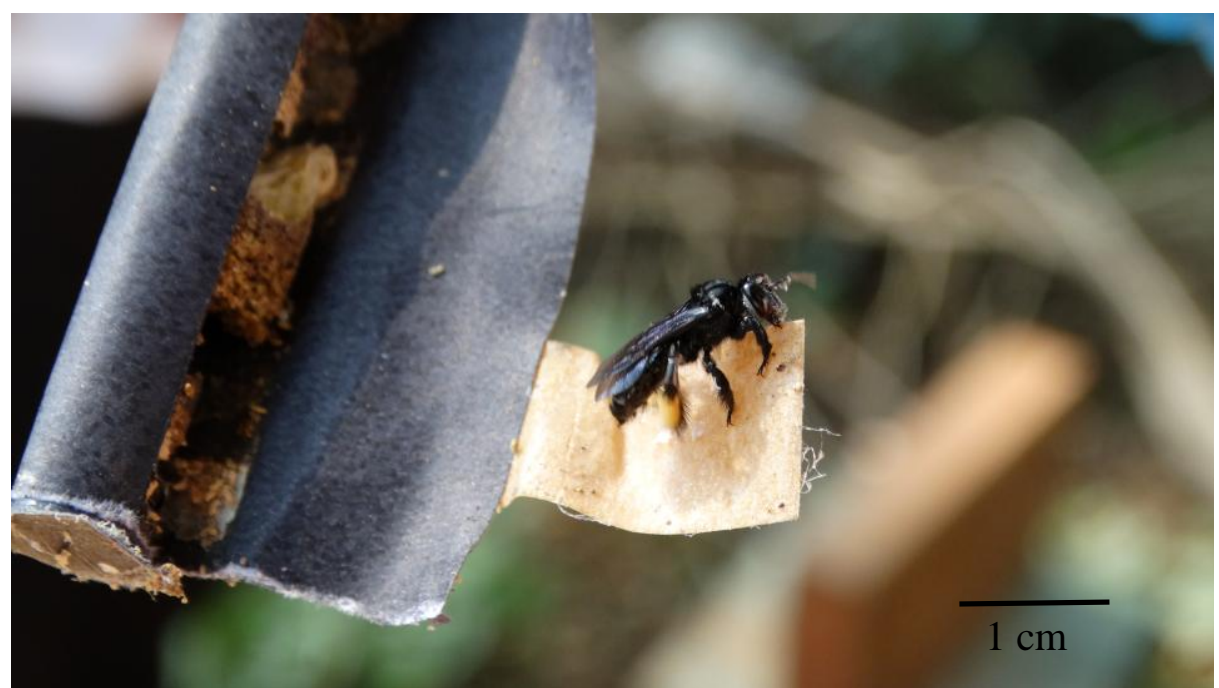

Figura 1: Indivíduo adulto de Tetrapedia diversipes recém-emergido (Foto por Natália Araujo).

Cada ninho é construído por uma única fêmea e pode ser constituído por um número diferente de células, variando de uma a sete. É comum o reuso dos ninhos antigos pelas gerações subsequentes, a nova fêmea limpa o orifício removendo as fezes antigas e o material arenoso e começa a construção do novo ninho. Ocasionalmente foram observados ninhos abandonados antes de estarem completos (quando a fêmea morre durante o forrageamento, por exemplo), nestes casos eles foram ocupados por outra fêmea alguns dias depois. Nestas ocasiões, em um mesmo ninho, há imaturos em duas fases sequenciais de desenvolvimento, provenientes de duas fêmeas distintas (Alves-dosSantos et al. 2002).

A espécie T. diversipes é um modelo interessante para se estudar o fenômeno da diapausa, pois apresenta duas gerações anuais (bivoltina) sendo que uma entra em diapausa e a outra não. Os indivíduos que nascem na primeira geração (ninhos fundados na primavera), e não entram em diapausa, têm o desenvolvimento mais acelerado em relação aos indivíduos da segunda geração (ninhos fundados no final do verão e no outono), que entram em diapausa. Foi observado que o tempo de desenvolvimento em $T$. diversipes varia de 21 a 366 dias. Essa grande variação no tempo indica um período de diapausa principalmente para os indivíduos de ninhos fundados no final do verão e no 
outono (Cordeiro 2009). Nos meses mais frios e secos (junho a agosto) o desenvolvimento cessa na fase de larva madura (estágio larval que precede a formação da pupa, também chamado $5^{\circ}$ ínstar larval) (Figura 2).

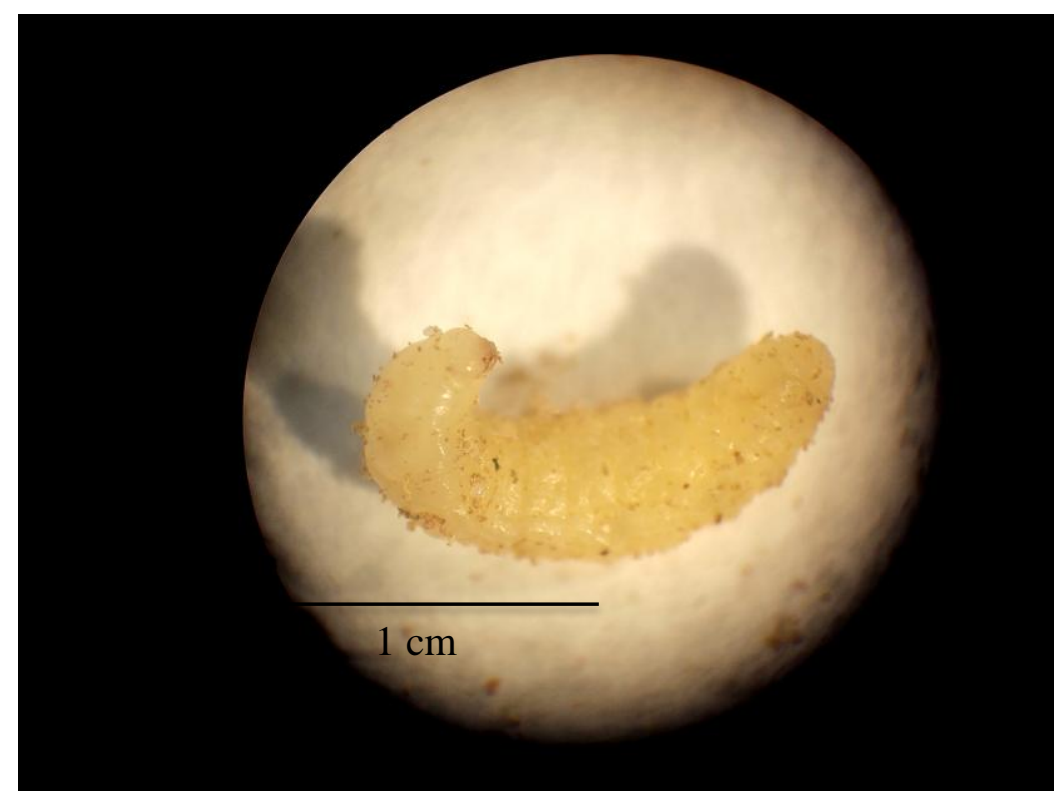

Figura 2: Larva no $5^{\circ}$ ínstar de Tetrapedia diversipes (Foto por Natália Araujo).

A maioria dos trabalhos focando o fenômeno da diapausa em insetos analisou a expressão de genes em espécies de clima temperado, e mantidas sob condições de laboratório. Tetrapedia diversipes é uma espécie tropical que possui dois modos de desenvolvimento ao longo do ano, o que permite analisar o perfil de expressão de genes de amostras coletadas diretamente na natureza, sem a necessidade de manipulação das condições externas para indução da diapausa. O padrão de expressão gênica dessa espécie será importante para estudos comparativos com outras espécies de insetos que também entram em diapausa. Ainda, poderá fornecer evidências evolutivas sobre as vias metabólicas e redes de interação gênica conservadas, ou não, entre organismos filogeneticamente mais relacionados, como outros Hymenoptera. 


\section{Objetivos}

O principal objetivo deste trabalho foi identificar os genes diferencialmente expressos entre larvas em diapausa e não diapausa de T. diversipes, e comparar os dados obtidos com os descritos na literatura para diferentes organismos e fases do desenvolvimento em que a diapausa ocorre.

\section{Material e Métodos}

\subsection{Coleta}

Foram coletadas larvas de $T$. diversipes em não diapausa de $1^{\circ}$ ao $5^{\circ}$ ínstar da primeira geração (coletadas em novembro e dezembro de 2012) e da segunda geração (coletadas em março e abril de 2013), e no $5^{\circ}$ ínstar em diapausa (julho e agosto de 2013). As larvas foram coletadas em ninhos-armadilha mantidos em ambiente natural. Os ninhos-armadilha consistem de tubos de cartolina, com dimensões de $5,8 \mathrm{~cm}$ ou $8,5 \mathrm{~cm}$ de comprimento e diâmetro de 0,6 cm (Figura 3), alojados em blocos de madeira de 30 $\mathrm{cm}$ de comprimento, $15 \mathrm{~cm}$ de altura e $5 \mathrm{~cm}$ de espessura (Figura 4) (Cordeiro, 2009).

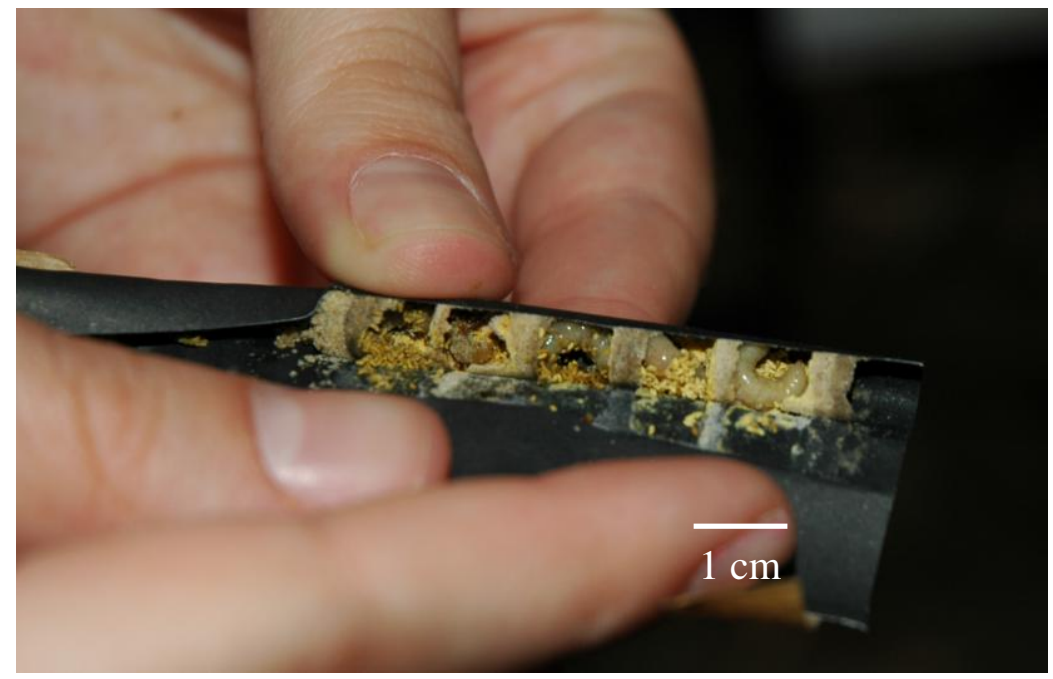

Figura 3: Ninho de Tetrapedia diversipes construído no tubo de cartolina alocado no bloco de madeira (Foto por Davis Santana). 


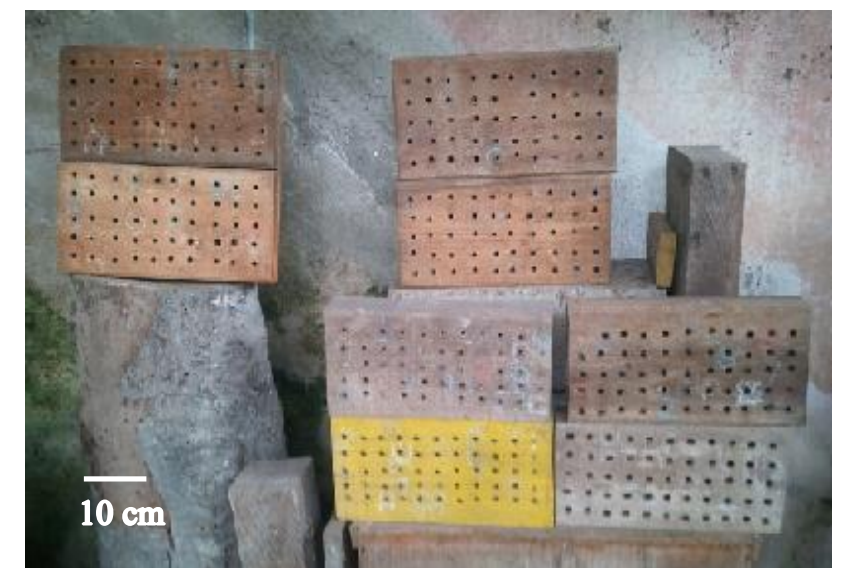

Figura 4: Blocos de madeira onde são alocados os ninhos-armadilha feitos de cartolina.

Os ninhos utilizados pelas fêmeas e quando finalizados (após o orifício de entrada ser fechado) foram observados periodicamente para a coleta das larvas no estágio desejado. Quando coletadas, as larvas foram imediatamente armazenadas à $-80^{\circ} \mathrm{C}$ até a extração de RNA.

\subsection{Extração de RNA, DNA e Sequenciamento}

O RNA total foi individualmente extraído de 27 larvas. Cada indivíduo foi macerado com um pistilo em Nitrogênio líquido e seguiu-se a extração utilizando o RNeasy Mini Kit (Quiagen - Austin, Texas). Posteriormente, as extrações foram agrupadas em nove pools, correspondentes ao RNA de três larvas cada (Tabela 1).

Tabela 1: Agrupamento de 27 larvas em nove pools de acordo com a fase (não diapausa e diapausa), geração $\left(1^{\mathrm{a}}\right.$ ou $\left.2^{\mathrm{a}}\right)$ e ínstares larvais $\left(1^{\mathrm{o}}\right.$ ao $\left.5^{\circ}\right)$.

\begin{tabular}{|c|c|c|c|}
\hline Fase & Geração & $\begin{array}{c}\text { Identificação } \\
\text { dos pools (três } \\
\text { larvas cada) }\end{array}$ & Ínstares \\
\hline \multirow{6}{*}{ Não Diapausa } & & 1 & $1^{\circ}$ a $4^{\circ}$ \\
\hline & $1^{\mathrm{a}}$ & 2 & $2^{\circ}$ a $5^{\circ}$ \\
\hline & & 3 & $5^{\circ}$ \\
\hline & & 4 & $5^{\circ}$ \\
\hline & $2^{\circ}$ & 5 & $1^{\circ} \mathrm{a} 4^{\circ}$ \\
\hline & & 6 & $2^{\circ}$ a $5^{\circ}$ \\
\hline \multirow{3}{*}{ Diapausa } & & 1 & $5^{\circ}$ \\
\hline & $2^{o}$ & 2 & $5^{\circ}$ \\
\hline & & 3 & $5^{\circ}$ \\
\hline
\end{tabular}


O RNA foi quantificado por espectrofotometria no aparelho Epoch $^{\mathrm{TM}}$ Spectrophotometer System (Winooski, USA). A qualidade do RNA, em relação a fragmentação, foi inferida por eletroforese. Foram aplicados $2 \mu \mathrm{l}$ de cada amostra em gel de agarose a 1.0\%, corados com Gel Red 10.000x (Biotium, USA), seguido por visualização com luz UV.

A montagem da biblioteca e o sequenciamento foram realizados pela empresa Macrogen (Coréia do Sul). Nove bibliotecas foram construídas, uma para cada pool de larvas, seguindo o protocolo para RNASeq. Foram sequenciadas seis bibliotecas por lane na plataforma Illumina HiSeq 2000 o que gerou aproximadamente 50 milhões de paired reads por biblioteca.

Para a obtenção do DNA, foi utilizado o tecido que restou no pistilo usado para maceração das larvas no Nitrogênio líquido (na etapa de extração de RNA). O pistilo foi imergido em $200 \mu \mathrm{l}$ de solução Chelex® 100 (Bio-Rad UK) até que o tecido se soltasse. Esta solução foi incubada por 30 minutos a $56^{\circ} \mathrm{C}$ seguido por cinco minutos a $100^{\circ} \mathrm{C}$. A amostra foi centrifugada por três minutos a $14000 \mathrm{rpm}$ e o sobrenadante foi usado como molde em reações de PCR para a identificação da espécie por DNA barcode. Isso foi necessário, pois os ninhos de $T$. diversipes são especificamente parasitados pela outra espécie de abelha da mesma tribo, Coelioxoides waltheriae. A região do DNA barcode, o gene Cytochrome c oxidase I (COI), foi amplificada com primers MtD9 e BarbeeF, seguindo as condições publicadas por Françoso e Arias (2013). Os produtos de PCR foram separados em gel de agarose a 0.8\%, corados com Gel Red 10.000x (Biotium, USA) e visualizados em luz UV. Os produtos de PCR foram purificados com ExoSAPIT® (USB, Corporation, USA) e as reações de sequenciamento foram realizadas seguindo as recomendações do fabricante, usando o Big Dye Terminator Kit (Applied Biosystem). O sequenciamento foi realizado pelo Serviço de Sequenciamento de DNA (SSDNA) do 
Departamento de Bioquímica na Universidade de São Paulo - IQUSP. As sequências foram visualizadas no programa Geneious v5.1 (Drummond et al. 2010) e foram comparadas ao banco de dados do NCBI utilizando a ferramenta Blastn para identificação de $T$. diversipes ou $C$. waltheriae.

\subsection{Limpeza e Montagem dos transcritos}

A qualidade do sequenciamento Illumina foi visualizada no programa FASTQC0.10.1 (http://www.bioinformatics.babraham.ac.uk/projects/fastqc/). Devido ao viés na composição nucleotídica gerado pela montagem da biblioteca (Hansen et al. 2010), as 14 primeiras bases de cada read foram retiradas usando o programa FASTX-0.0.13 ("FASTX-Toolkit" 2010). Os adaptadores do sequenciamento Illumina, reads menores que 31 bases e com valor de qualidade phred (Cock et al. 2010) inferior a 30 foram retirados utilizando o programa SeqYclean (Zhbannikov 2013).

A normalização digital foi feita no programa Trinity utilizando todas as bibliotecas de larvas sequenciadas. Esta normalização é uma etapa opcional que tem como objetivo diminuir a demanda de capacidade computacional e o tempo de análises requerido sem impactar significativamente na qualidade da montagem dos contigs (Brown et al. 2012)

A montagem foi realizada usando o programa Trinity-2.0.6 (Grabherr et al. 2011). Foram feitos testes utilizando diferentes parâmetros (APÊNDICE A, Tabelas A1, A2 e A3) e a melhor montagem foi escolhida baseada nos resultados do programa BUSCOv1.1b1 (Simao et al. 2015) e nas estatísticas do script TrinityStats.pl.

O programa BUSCO ("Benchmarking Universal Single-Copy Orthologs”) utiliza um banco de dados de genes ortólogos de cópia única para comparações de montagens de genomas e transcriptomas (Simao et al. 2015). Há nesse banco de dados 2675 genes ortólogos em artrópodes. Cada montagem é avaliada quanto à presença ou ausência 
destes genes, sendo os presentes classificados como completos, duplicados (genes completos com mais de uma cópia) e fragmentados (genes parcialmente recuperados) (Simao et al. 2015). As duas últimas categorias não são esperadas em montagem de boa qualidade. Os parâmetros utilizados para todas as etapas seguem no APÊNDICE B.

\subsection{Expressão diferencial e anotação}

Para a expressão diferencial as reads obtidas do pool de larvas número 6 foram retiradas das análises, pois uma das larvas do pool foi coletada tardiamente e haveria possibilidade de que ela estivesse em diapausa. Esse cuidado foi tomado, pois esse pool de larvas poderia provocar ruídos nas análises. Sendo assim, foram alinhadas as reads de cinco transcriptomas de larvas em não diapausa e de três de larvas em diapausa (cada biblioteca separadamente).

O alinhamento das reads foi feito utilizando o Bowtie2-2.2.5 (Langmead \& Salzberg 2012) e a contabilização das mesmas foi feita pelo RSEM-1.2.22 (Li \& Dewey 2011), ambos os pacotes estão incluídos no Trinity. Este alinhamento e contagem foram feitos para cada conjunto de reads limpas de cada biblioteca. Estas informações foram reunidas em uma matriz que foi usada como input nos programas de expressão diferencial.

A expressão diferencial dos genes foi calculada pelos programas DESeq2 1.10.0 (Love et al. 2014) e EdgeR 3.12.0 (Robinson et al. 2010). Esses programas foram escolhidos com base nas analises comparativas feitas por Ching et al. (2014) onde cinco programas que calculam a expressão diferencial (DESeq, EdgeR, DESeq2, sSeq e EBSeq) foram testados e DESeq2 e EdgeR foram apontados, em geral, como os pacotes com melhor desempenho. O protocolo para análise de expressão com ambos está incluído no Trinity. Os parâmetros utilizados foram os default (valor p ajustado (FDR) $<0.001$ e fold change =2). O heat map com os transcritos diferencialmente expressos foi gerado no 
pacote R 3.2.1 com base nos dados de expressão diferencial identificados pelo programa DESeq2 e a anotação foi feita apenas para os transcritos que foram identificados como diferencialmente expressos pelos dois programas (DESeq2 e EdgeR).

A anotação de todo o transcriptoma foi feita por Blastx usando o programa Annocript 1.1.2 (Musacchia et al. 2015) e os bancos de dados Swiss-Prot e UniRef ( $p$ value 1e-5). A anotação dos genes diferencialmente expressos foi feita por Blastx através do programa Blast2GO-3.0.10 (Conesa et al. 2005) usando o banco de dados curado Swiss-Prot (p-value 1e-10) e também pelo Annocript. Em ambos os casos foram selecionados o melhor Blast hit. Os genes anotados foram mapeados de acordo com os termos do Gene Ontology (GO) pelo programa Annocript e com as vias presentes no banco de dados "Kyoto Encyclopedia of Genes and Genomes" (KEGG) usando Blast2GO-3.0.10.

\section{Resultados}

\subsection{Limpeza, montagem e anotação do transcriptoma das larvas de $T$. diversipes}

A limpeza das reads com os programas FASTX e SeqYclean reduziu a quantidade de reads de 534.586.824 para 464.537.144. E após a normalização digital este número caiu para 29.650 .152 reads.

A montagem de novo utilizando as reads normalizadas resultou em 29.320 transcritos correspondentes a 29.298 genes. O tamanho médio dos contigs foi 580pb e N50 igual a 1.781 pb (números gerados pelo script TrinityStats.pl). O valor de N50 significa que $50 \%$ dos transcritos montados tiveram no mínimo esse tamanho (Lander et al. 2001). Foram realinhadas ao transcriptoma $98,73 \%$ das reads limpas.

A análise global de todos os transcritos montados quando feita pelo programa BUSCO, ou seja, com o banco de dados dos 2.675 genes ortólogos em artrópodes, 
resultou em 2063 (77\%) identificados como completos e com cópia única, 110 (4.1\%) como completos e duplicados, 141 (5.2\%) fragmentados e 361 (13\%) não foram encontrados.

A anotação de todos os transcritos pelo programa Annocript resultou em 16.237 sequências como potenciais codificadoras, entre elas estão sequências homólogas aos bancos de dados SwissProt/UniRef, a domínios proteicos e sequências possivelmente codificantes mas não representadas nestes bancos de dados, ou seja, apresentam "Open Reading Frames" (ORFs) maiores que 100 bases. Foram anotados no SwissProt 8.928 genes e ao UniRef 13.223 genes, 76 transcritos correspondem a RNA ribossômico e 892 têm potencial para ser RNA não codificantes longos (lncRNA). A maioria dos genes anotados no UniRef foi homólogo aos genes do gênero Bombus $(2.296 ; 17.3 \%$ dos transcritos), seguido pelo genêro Apis $(1.667 ; 12.6 \%$ dos transcritos) e M. rotundata (1.390; $10.5 \%$ dos transcritos).

Os genes anotados foram classificados entre as principais categorias de classificação de Gene Ontology (GO) (Processos Biológicos (PB), Funções Moleculares (FM) e Componentes Celulares (CC)). O consórcio de GO tem o objetivo de produzir um vocabulário comum para descrever funções de genes e seus produtos. PB se refere a processos biológicos em que os genes contribui, frequentemente envolve transformação química e física. FM é definido como atividade bioquímica do produto do gene (incluindo ligação específica a ligantes ou estruturas. Descreve o que é feito sem especificar onde ou quando o evento ocorre. $\mathrm{CC}$ se refere ao local na célula onde o produto de um gene é ativo (Ashburner et al. 2000). 
$\mathrm{Na}$ categoria $\mathrm{PB}$ os termos predominantes foram relacionados a "transcription, DNA-dependent", "translation" e "regulation of transcription, DNA-dependent" (Figura $5)$.

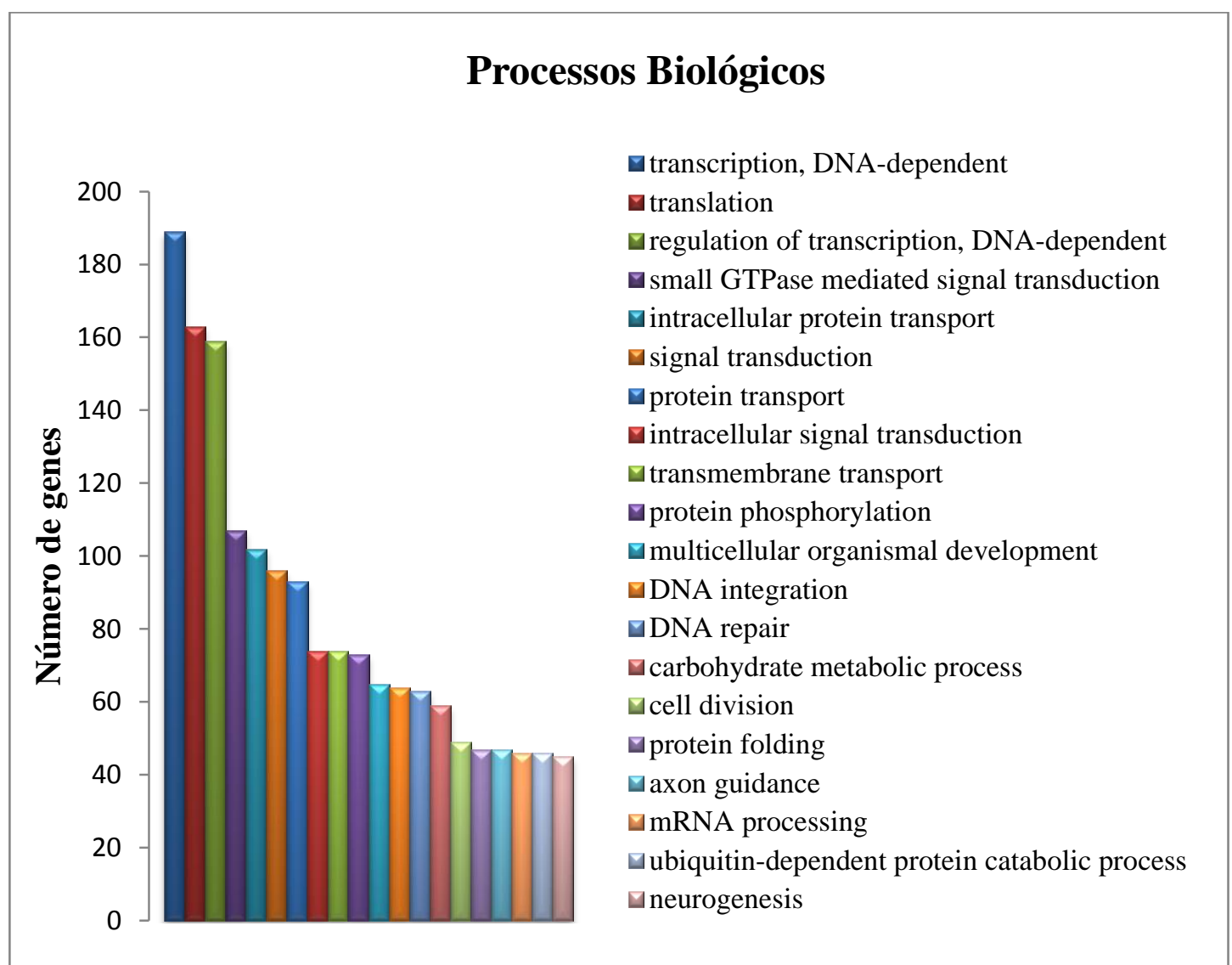

Figura 5: Genes anotados a partir da análise do transcriptoma das larvas de Tetrapedia diversipes e suas distribuições de acordo com os termos do Gene Ontology na categoria "Processos Biológicos". Na figura constam os termos mais representados. 
Na categoria FM predominaram os termos ATP "binding”, "metal ion binding” e “zinc ion binding” (Figura 6).

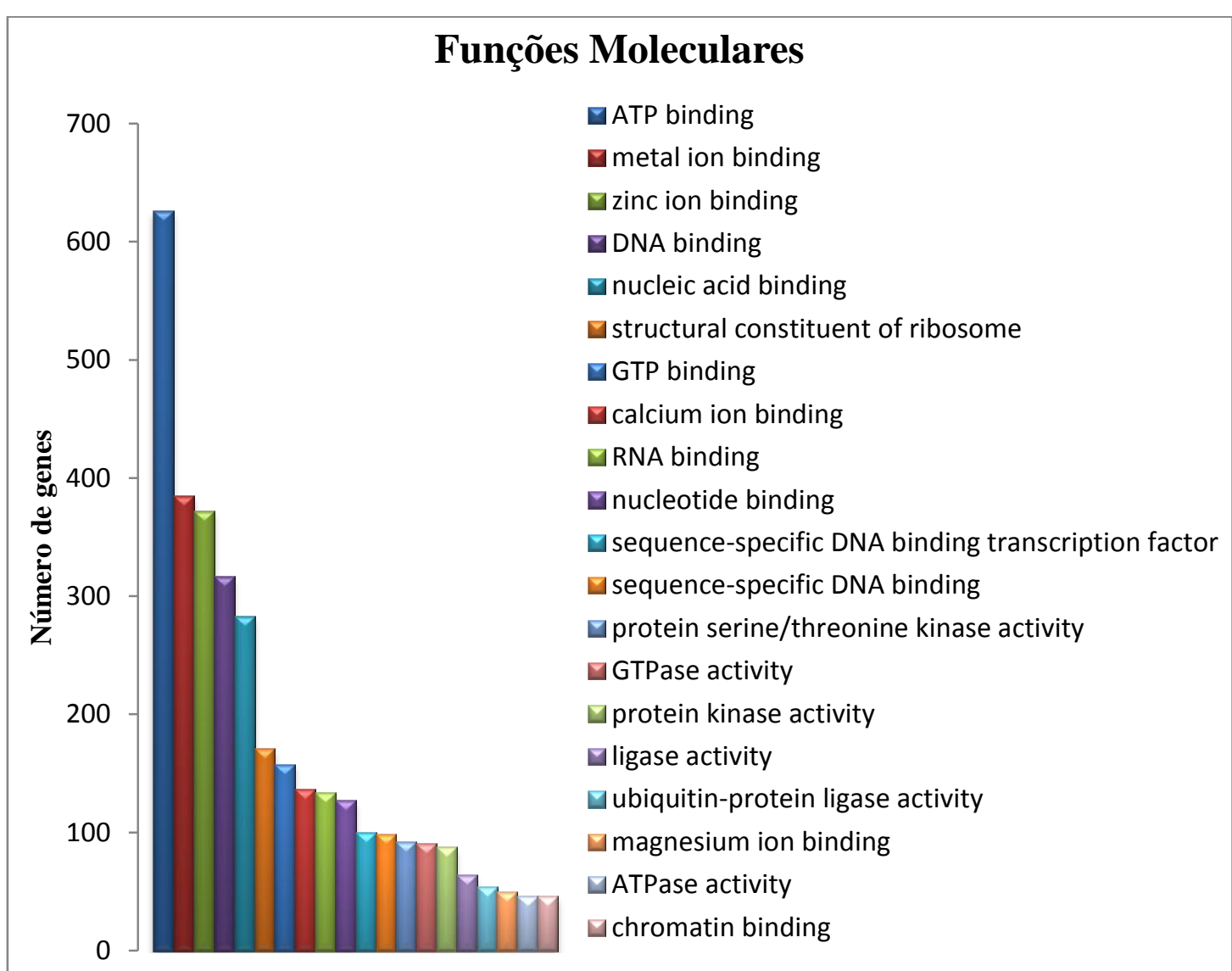

Figura 6: Genes anotados a partir da análise do transcriptoma das larvas de Tetrapedia diversipes e suas distribuições de acordo com os termos do Gene Ontology na categoria "Funções Moleculares". Na figura constam os termos mais representados. 
E na categoria CC, a maioria dos genes foi incluída nos termos "nucleus", “integral to membrane" e "cytoplasm” (Figura 7).

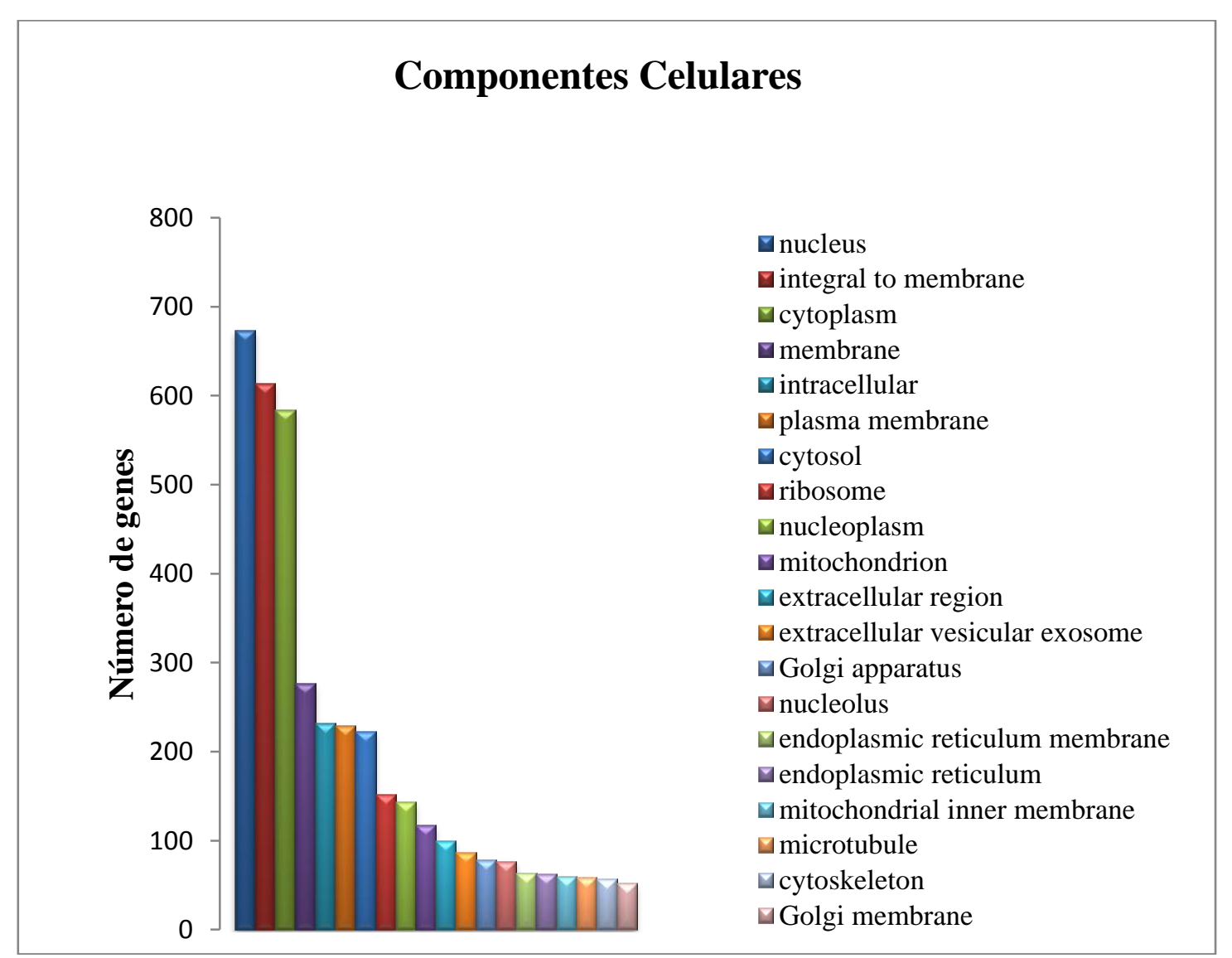

Figura 7: Genes anotados a partir da análise do transcriptoma das larvas de Tetrapedia diversipes e suas distribuições de acordo com os termos do Gene Ontology na categoria "Componentes Celulares". Na figura constam os termos mais representados.

\subsection{Expressão diferencial e anotação}

O programa DESeq2 identificou 349 transcritos diferencialmente expressos (Figura 8), sendo 120 com a expressão aumentada durante a diapausa e 229 com a expressão reduzida. É possível observar um padrão muito distinto de expressão entre as larvas em não diapausa e diapausa. Vale ressaltar que as larvas em $5^{\circ}$ ínstar da segunda geração (Larvas4), que entrariam em diapausa, apresentam um padrão de expressão 
intermediário, provavelmente referente a uma fase descrita na literatura como prédiapausa (Kostál, 2006) (Figura 8).

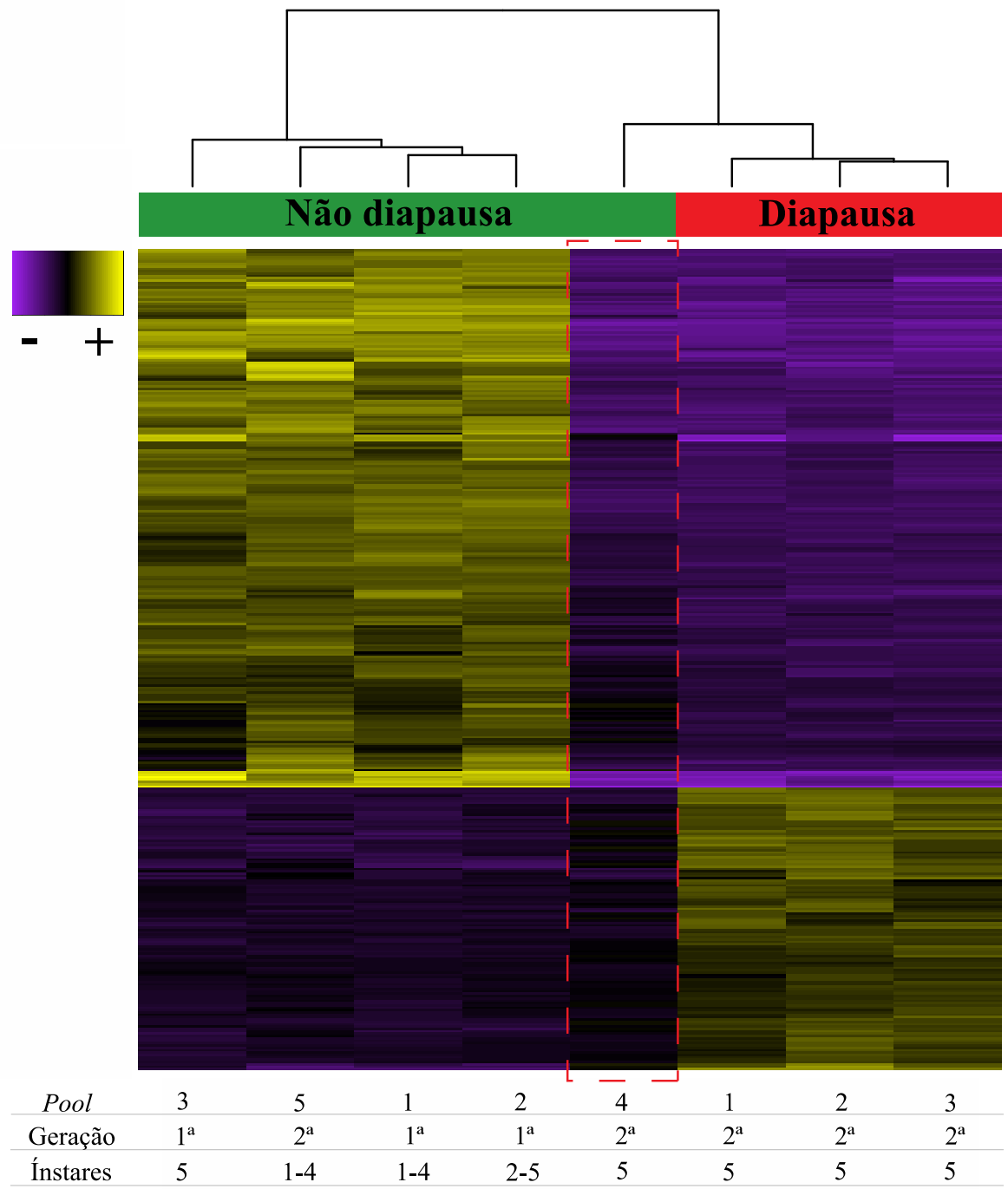

Figura 8: Heat map dos 349 transcritos diferencialmente expressos identificados pelo programa DESeq2 entre larvas em não diapausa e diapausa. Os valores de expressão estão padronizados pelo "Z-score", onde a cor amarela representa alta expressão e a roxa baixa expressão. Cada coluna é uma biblioteca constituída por um pool de três larvas (larvas em não diapausa de 1 a 5 e larvas em diapausa de 1 a 3 ) e cada linha é um gene. A coluna pontilhada se refere às larvas que provavelmente estavam na fase de pré-diapausa. Pool, Geração e Ínstares estão de acordo com a Tabela 1.

O programa EdgeR resultou em 384 transcritos diferencialmente expressos. Comparando os resultados obtidos pelos dois programas (DESeq2 e EdgeR), 196 transcritos foram identificados em comum. Dentre os 196 transcritos, apenas 74 foram anotados usando o programa Blast2GO, e nas comparações com os bancos de dados SwissProt e UniRef pelo Annocript, 74 foram igualmente anotados ao SwissProt e 107 
transcritos foram anotados ao UniRef. No entanto, desses 107 transcritos anotados, 53 foram também anotados ao SwissProt, 13 foram novas anotações e os 41 restantes foram "PREDICTED Uncharacterized protein" e "Uncharacterized protein", resultando em 87 transcritos anotados pelos dois programas usando os dois bancos de dados. Os 87 transcritos representam 82 genes, sendo que 27 apresentaram alta expressão e 55 baixa expressão nas larvas em diapausa (Tabela 2).

Tabela 2: Características dos 87 transcritos e seus níveis de expressão (alta ou baixa) em larvas de $T$. diversipes em diapausa. Na tabela constam: Nome dos transcritos, a qual gene se refere (Anotação), o comprimento do transcrito em pb e o e-value referente ao melhor hit do Blastx.

\begin{tabular}{|c|c|c|c|c|}
\hline $\begin{array}{c}\text { Nível de } \\
\text { expressão }\end{array}$ & $\begin{array}{c}\text { Nome do } \\
\text { transcrito } \\
\end{array}$ & Anotação & $\begin{array}{c}\text { Comprime } \\
\text { nto (pb) }\end{array}$ & e-value \\
\hline \multirow{30}{*}{$\begin{array}{c}\text { Transcritos } \\
\text { com alta } \\
\text { expressão }\end{array}$} & TR11178|c0_g1 & Twitchin & 8535 & $0.0 \mathrm{e} 0$ \\
\hline & TR17849|c0_g1 & Myosin regulatory light chain 2 & 642 & $8.5 e-68$ \\
\hline & TR12529|c0_g1 & Tubby-related protein 4 & 957 & $1.6 e-43$ \\
\hline & TR5353|c0_g1 & Tubby-related protein 4 & 2318 & $1.5 e-37$ \\
\hline & TR6726|c0_g1 & PREDICTED Tubby-related protein 4 & 495 & $4.0 \mathrm{e}-66$ \\
\hline & TR1235|c0_g1 & Prominin-like protein & 4235 & $2.8 \mathrm{e}-65$ \\
\hline & TR23157|c0_g1 & Teneurin-m & 3568 & $0.0 \mathrm{e} 0$ \\
\hline & TR8933|c0_g1 & Protein yellow & 2297 & $6.1 \mathrm{e}-72$ \\
\hline & TR13585|c0_g1 & $A B C$ transporter $G$ family member 22 & 3675 & $9.2 \mathrm{e}-100$ \\
\hline & TR1928|c0_g1 & Lactosylceramide 4-alpha-galactosyltransferase & 2374 & $7.5 \mathrm{e}-36$ \\
\hline & TR6177|c0_g1 & Tyrosine-protein kinase transmembrane receptor Ror & 751 & $3.6 e-95$ \\
\hline & TR12793|c0_g1 & Actin, partial & 290 & $1.4 \mathrm{e}-63$ \\
\hline & TR4087|c0_g1 & Rho-related BTB domain-containing protein 2 & 2840 & $3.8 \mathrm{e}-72$ \\
\hline & TR10418|c0_g1 & Actin & 533 & $2.8 \mathrm{e}-15$ \\
\hline & TR26289|c0_g1 & 15-hydroxyprostaglandin dehydrogenase $[N A D(+)]$ & 1846 & $7.6 e-27$ \\
\hline & TR10707|c0_g1 & Fasciclin-1 & 1056 & $2.6 e-128$ \\
\hline & TR19978|c0_g1 & Myosin light chain alkali & 284 & $4.5 e-47$ \\
\hline & TR944|c0_g1 & Plexin-A4 & 1336 & $1.8 \mathrm{e}-38$ \\
\hline & TR19540|c0_g1 & Ubiquitin carboxyl-terminal hydrolase 3 & 3091 & $7.7 e-119$ \\
\hline & TR1663|c0_g1 & Zinc finger protein ush & 1802 & $9.3 e-46$ \\
\hline & TR27583|c0_g1 & Tubulin alpha chain, partial & 556 & $1.6 \mathrm{e}-37$ \\
\hline & TR15616 $\mid \mathrm{c} 0 \_\mathrm{g} 1$ & Protein toll & 1219 & $1.6 \mathrm{e}-31$ \\
\hline & TR27394|c0_g1 & Protein toll & 246 & $3.0 \mathrm{e}-24$ \\
\hline & TR14118|c0_g1 & SAM and SH3 domain-containing protein 1 & 1981 & $6.1 \mathrm{e}-17$ \\
\hline & TR19094|c0_g1 & Growth differentiation 11 & 1921 & $1.9 \mathrm{e}-74$ \\
\hline & TR19097|c2_g1 & $\begin{array}{l}\text { PREDICTED histone-lysine } N \text {-methyltransferase } \\
\text { SETMAR-like }\end{array}$ & 252 & $1.0 \mathrm{e}-07$ \\
\hline & TR3988|c0_g1 & Tetraspanin/CD151 antigen & 3315 & 0.0 \\
\hline & TR19810|c0_g1 & PREDICTED RNA binding protein fox-1 homolog 2 & 642 & $8.0 \mathrm{e}-07$ \\
\hline & TR14495|c0_g2 & PREDICTED titin isoform X4 & 3825 & $9.0 \mathrm{e}-40$ \\
\hline & TR16471|c0_g1 & PREDICTED neuromodulin & 948 & $1.0 \mathrm{e}-103$ \\
\hline \multirow{6}{*}{$\begin{array}{l}\text { Transcritos } \\
\text { com baixa } \\
\text { expressão }\end{array}$} & TR19701|c0_g1 & Regucalcin & 1335 & $4.9 \mathrm{e}-61$ \\
\hline & TR10667|c0_g1 & Uncharacterized oxidoreductase YrbE & 399 & $8.3 e-27$ \\
\hline & TR1018|c0_g1 & Uncharacterized oxidoreductase YrbE & 1019 & $2.7 \mathrm{e}-40$ \\
\hline & TR13928|c0_g1 & Facilitated trehalose transporter & 6434 & $5.5 e-91$ \\
\hline & TR15010|c0_g1 & Alcohol dehydrogenase $[N A D P(+)] A$ & 1611 & $1.2 \mathrm{e}-93$ \\
\hline & TR13578|c0_g1 & Venom acid phosphatase Acph-1 & 1532 & $1.1 \mathrm{e}-49$ \\
\hline
\end{tabular}




\begin{tabular}{|c|c|c|c|c|}
\hline & TR19074|c0_g1 & Mitochondrial 2-oxoglutarate/malate carrier protein & 1507 & $1.7 \mathrm{e}-89$ \\
\hline & TR5611|c0_g1 & Acyl-CoA binding protein homolog & 1234 & $7.8 \mathrm{e}-26$ \\
\hline & TR20665|c0_g1 & Endocuticle structural glycoprotein $\mathrm{SgAbd-1}$ & 851 & $5.7 e-24$ \\
\hline & TR23661|c0_g1 & Proton-coupled amino acid transporter 1 & 3096 & $7.7 e-70$ \\
\hline & TR24141|c0_g1 & Peroxisomal membrane protein PMP34 & 1099 & $4.0 \mathrm{e}-84$ \\
\hline & TR12531|c0_g1 & Lambda-crystallin homolog & 1101 & $6.0 \mathrm{e}-108$ \\
\hline & TR20939|c0_g1 & Glycerol-3-phosphate dehydrogenase 1-like protein & 425 & $1.0 \mathrm{e}-19$ \\
\hline & TR16433|c0_g1 & Protein spaetzle & 942 & $8.0 \mathrm{e}-16$ \\
\hline & TR18984|c0_g1 & Venom serine protease 34 & 1735 & $3.2 \mathrm{e}-120$ \\
\hline & TR23879|c0_g1 & Inositol oxygenase & 2239 & $4.8 \mathrm{e}-114$ \\
\hline & TR7130|c0_g1 & Mitochondrial pyruvate carrier 1 & 805 & $6.4 \mathrm{e}-43$ \\
\hline & TR9559|c0_g1 & PI-PLC X domain-containing protein 1 & 1979 & $6.2 \mathrm{e}-19$ \\
\hline & TR17187|c0_g1 & Kynurenine 3-monooxygenase & 1666 & $3.1 \mathrm{e}-175$ \\
\hline & TR3855|c0_g1 & Putative serine protease $\mathrm{K} 12 \mathrm{H} 4.7$ & 3639 & $1.4 \mathrm{e}-80$ \\
\hline & TR10990|c0_g1 & Innexin-7 & 1539 & $5.0 \mathrm{e}-96$ \\
\hline & TR10338|c0_g1 & Inosine-uridine preferring nucleoside hydrolase & 977 & $2.9 \mathrm{e}-39$ \\
\hline & TR3596|c0_g1 & Putative hydroxypyruvate isomerase & 825 & $6.7 \mathrm{e}-83$ \\
\hline & TR24492|c0_g1 & Aldose reductase & 1130 & $5.0 \mathrm{e}-118$ \\
\hline & TR24208|c0_g1 & Glutathione S-transferase & 1442 & $2.2 \mathrm{e}-46$ \\
\hline & TR11239|c0_g1 & Glutathione S-transferase & 859 & $2.6 e-54$ \\
\hline & TR23448|c0_g1 & $\mathrm{N}$-acetylneuraminate lyase & 1004 & $1.0 \mathrm{e}-49$ \\
\hline & TR3070|c0_g1 & Phospholipase A2 isozymes PA3A/PA3B/PA5 & 1460 & $1.1 \mathrm{e}-20$ \\
\hline & TR9362|c0_g1 & Cytochrome c & 1040 & $6.7 \mathrm{e}-66$ \\
\hline Transcritos & TR1546|c0_g1 & Mitochondrial pyruvate carrier 2 & 1419 & $1.3 e-33$ \\
\hline com baixa & TR14173|c0_g1 & Sepiapterin reductase & 1681 & $1.3 \mathrm{e}-40$ \\
\hline expressão & TR19118|c0_g1 & Fatty acid synthase & 5275 & $0.0 \mathrm{e} 0$ \\
\hline & TR22377|c0_g1 & Phosphotriesterase-related protein & 1443 & $1.8 \mathrm{e}-119$ \\
\hline & TR23672|c0_g1 & $\begin{array}{l}\text { Kynurenine/alpha-aminoadipate aminotransferase, } \\
\text { mitochondrial }\end{array}$ & 1431 & $1.3 \mathrm{e}-111$ \\
\hline & TR6658|c0_g1 & Hydroxymethylglutaryl-CoA lyase & 1032 & 4.0e-117 \\
\hline & TR13760|c0_g1 & Motor neuron and pancreas homeobox protein 1 & 3018 & $1.3 e-36$ \\
\hline & TR13358|c0_g1 & Chitin synthase 8 & 4521 & $1.7 \mathrm{e}-17$ \\
\hline & TR27653|c0_g1 & Probable peroxisomal acyl-coenzyme A oxidase 1 & 3274 & $0.0 \mathrm{e} 0$ \\
\hline & TR315|c0_g1 & $b(0,+)$-type amino acid transporter 1 & 2022 & $8.4 \mathrm{e}-112$ \\
\hline & TR16659|c0_g1 & Protein rolling stone & 1266 & $1.6 \mathrm{e}-19$ \\
\hline & TR12042|c0_g1 & Aminopeptidase $N$ & 1260 & $7.7 \mathrm{e}-61$ \\
\hline & TR23605|c0_g1 & Acyl-CoA synthetase family member 2 & 2438 & $8.7 e-143$ \\
\hline & TR18783|c0_g1 & UDP-glucuronosyltransferase 1-1 & 3300 & $1.1 \mathrm{e}-56$ \\
\hline & TR1317|c0_g1 & Trypsin $3 A 1$ & 1133 & $1.3 \mathrm{e}-45$ \\
\hline & TR24660|c0_g1 & GATA-binding factor $C$ & 1399 & $1.2 \mathrm{e}-60$ \\
\hline & TR598|c0_g1 & Monocarboxylate transporter 13 & 3495 & $1.4 \mathrm{e}-12$ \\
\hline & TR16631|c0_g1 & Flexible cuticle protein 12 & 887 & $8.0 \mathrm{e}-15$ \\
\hline & TR19042|c0_g1 & Niemann-Pick C1 protein & 4600 & $0.0 \mathrm{e} 0$ \\
\hline & TR24893|c0_g1 & Excitatory amino acid transporter 3 & 1781 & $6.1 \mathrm{e}-89$ \\
\hline & TR11885|c0_g1 & Nose resistant to fluoxetin protein 6 & 2748 & $2.3 e-29$ \\
\hline & TR1329|c0_g1 & Estrogen sulfotransferase & 1199 & $2.5 \mathrm{e}-44$ \\
\hline & TR3171|c0_g1 & $\begin{array}{l}\text { PREDICTED keratin type II cytoskeletal } 60 \mathrm{kDa} \\
\text { component III }\end{array}$ & 933 & $6.00 \mathrm{e}-34$ \\
\hline & TR23887|c0_g1 & $\begin{array}{l}\text { PREDICTED trans-1 2-dihydrobenzene-1 2-diol } \\
\text { dehydrogenase-like }\end{array}$ & 498 & $2.00 \mathrm{e}-52$ \\
\hline & TR17627|c0_g1 & PREDICTED orcokinin peptides-like isoform X1 & 843 & $6.00 \mathrm{e}-45$ \\
\hline & TR14999|c0_g1 & PREDICTED peritrophin-1 & 856 & $3.00 \mathrm{e}-18$ \\
\hline & TR19950|c1_g1 & PREDICTED protein starmaker-like & 378 & $8.00 \mathrm{e}-11$ \\
\hline & TR16|c0_g2 & PREDICTED protein G12-like isoform XI & 880 & $2.00 \mathrm{e}-53$ \\
\hline
\end{tabular}


Na classificação de GO para os 87 genes diferencialmente expressos, os termos predominantes na categoria PB foram relacionados a "mitochondrial pyruvate transport", “lipid metabolic process" e "protein transport” (Figura 9).

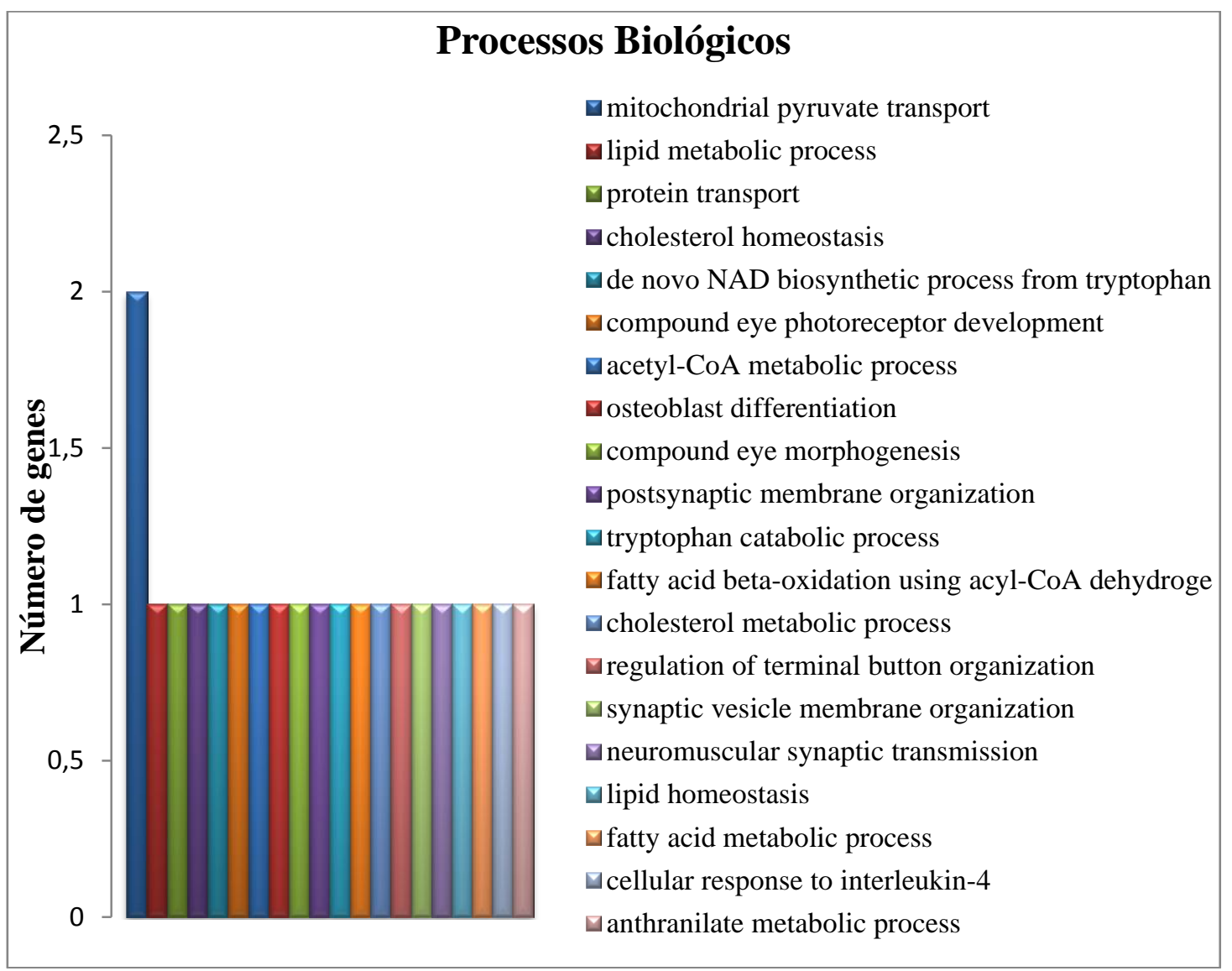

Figura 9: Genes anotados diferencialmente expressos entre larvas em não diapausa e diapausa de Tetrapedia diversipes e suas distribuições de acordo com os termos do Gene Ontology na categoria "Processos Biológicos". Na figura constam os termos mais representados. 
$\mathrm{Na}$ categoria FM predominaram os termos "calcium ion binding", "flavin adenine dinucleotide binding" e "zinc ion binding" (Figura 10).

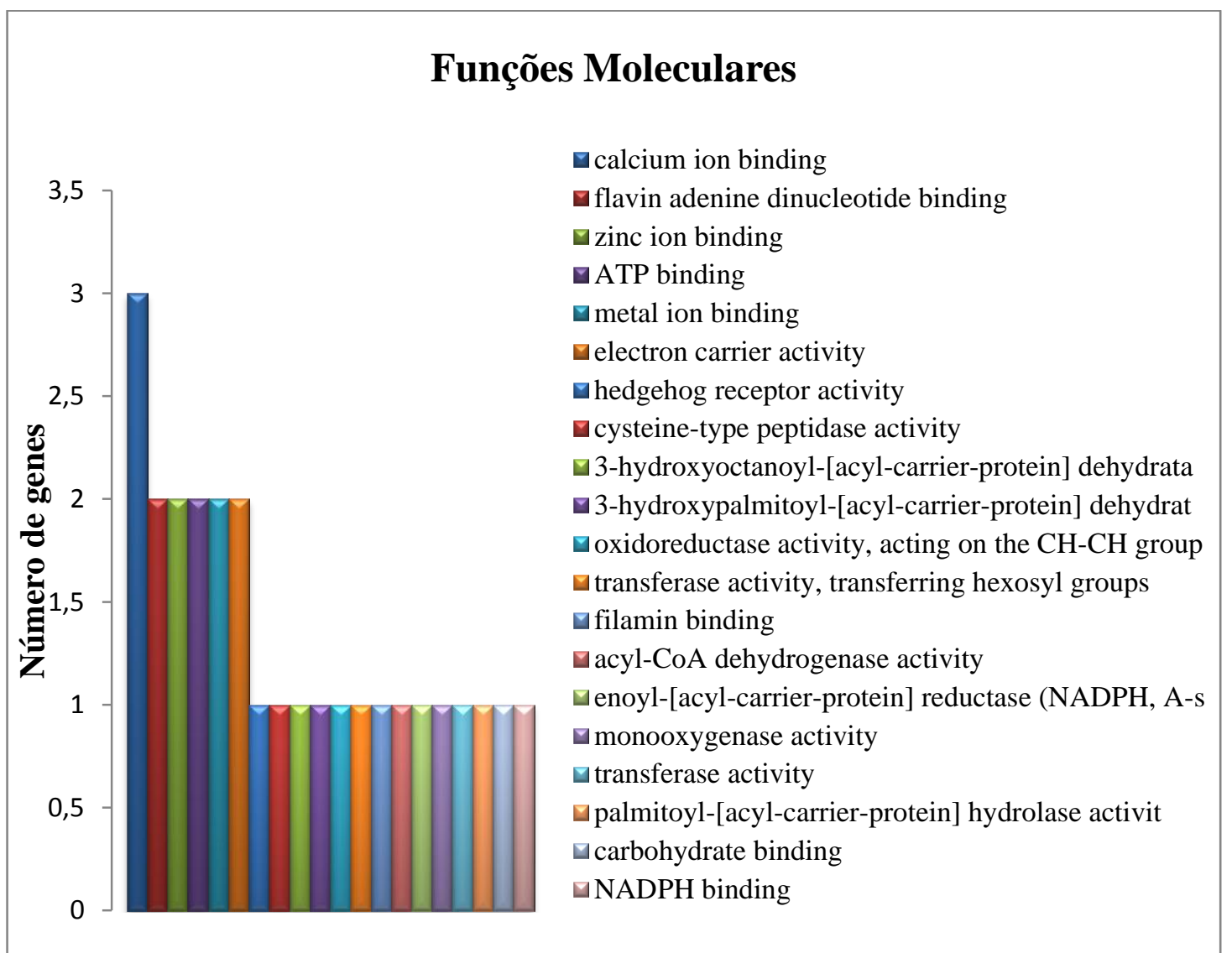

Figura 10: Genes anotados diferencialmente expressos entre larvas em não diapausa e diapausa de Tetrapedia diversipes e suas distribuições de acordo com os termos do Gene Ontology na categoria "Funções Moleculares". Na figura constam os termos mais representados. 
E na categoria de CC, a maioria dos genes foi incluída nos termos "integral to membrane", "cytoplasm" e "plasma membrane" (Figura 11).

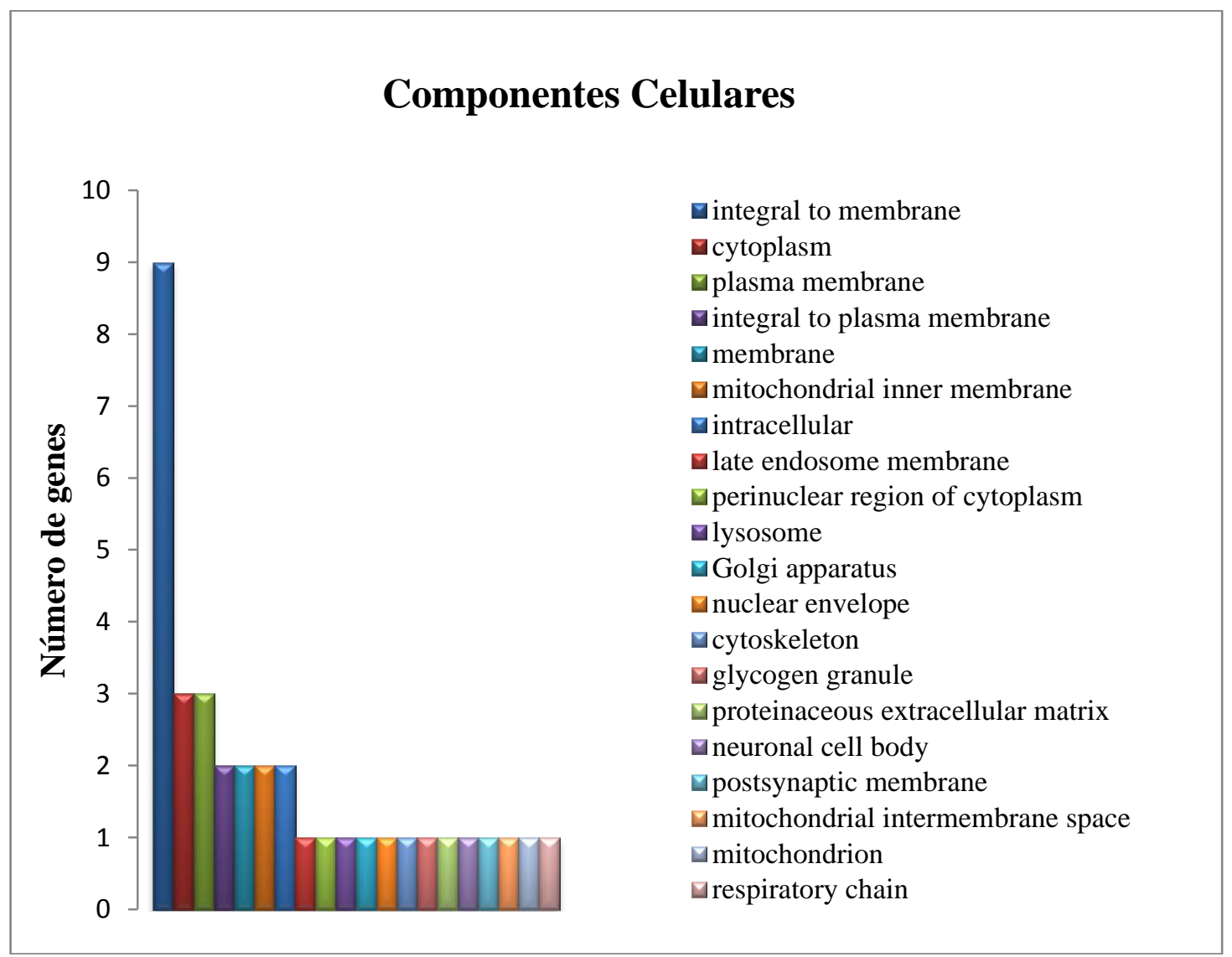

Figura 11: Genes anotados diferencialmente expressos entre larvas em não diapausa e diapausa de Tetrapedia diversipes e suas distribuição de acordo com os termos do Gene Ontology na categoria "Componentes Celulares". Na figura constam os termos mais representados. 
Os termos específicos para cada gene podem ser observados na Tabela 3.

Tabela 3: Genes anotados aos termos do Gene Ontology categorizados em "Processos Biológicos",

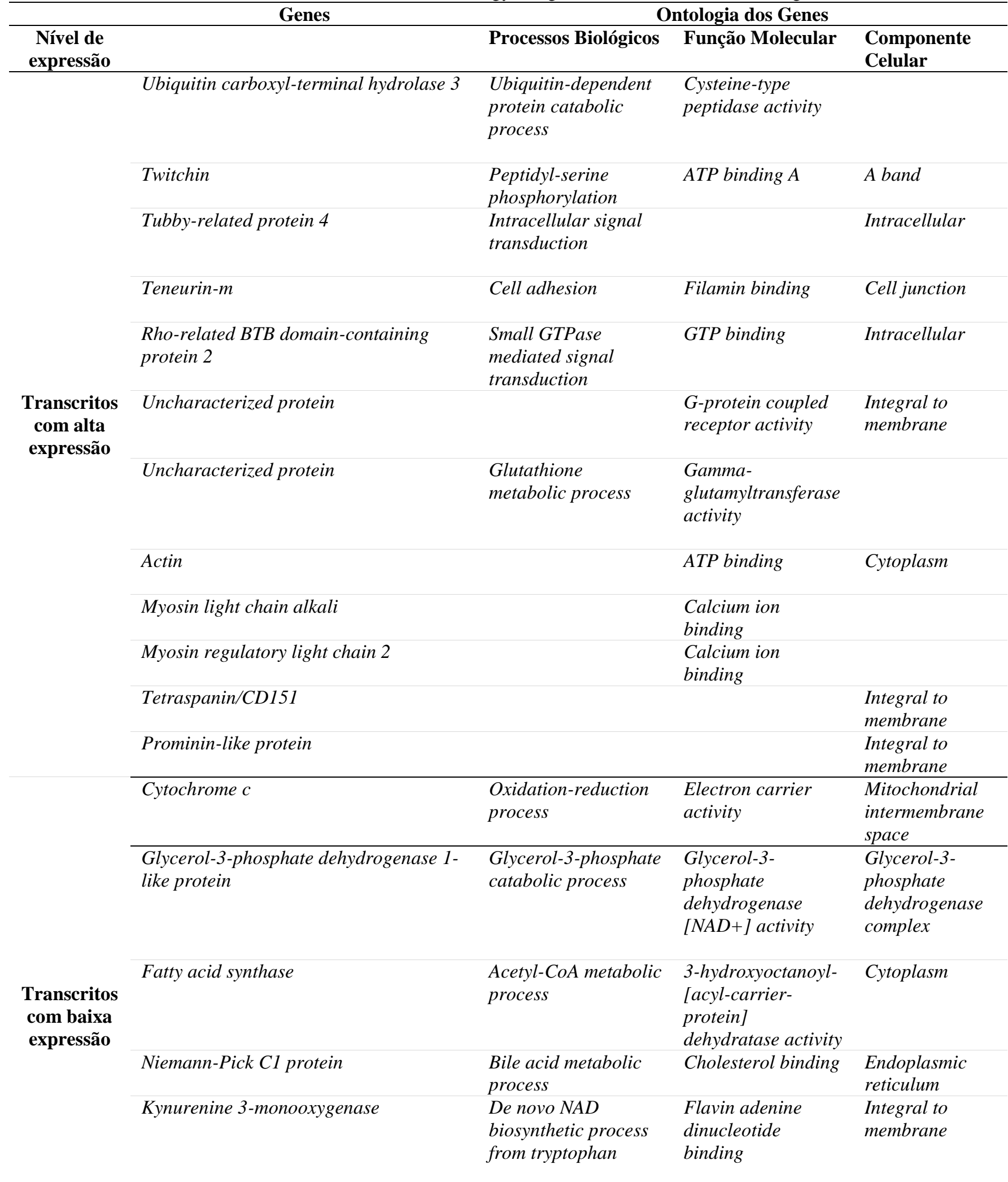




\begin{tabular}{llll}
$\begin{array}{l}\text { Probable peroxisomal acyl-coenzyme A } \\
\text { oxidase 1 }\end{array}$ & $\begin{array}{l}\text { Fatty acid beta- } \\
\text { oxidation }\end{array}$ & $\begin{array}{l}\text { Acyl-CoA } \\
\text { dehydrogenase } \\
\text { activity }\end{array}$ & $\begin{array}{l}\text { Peroxisome } \\
\text { Lambda-crystallin homolog }\end{array}$ \\
\hline $\begin{array}{l}\text { Fatty acid metabolic } \\
\text { process }\end{array}$ & $\begin{array}{l}\text { 3-hydroxyacyl-CoA } \\
\text { dehydrogenase } \\
\text { activity }\end{array}$
\end{tabular}

Mitochondrial pyruvate carrier $1 \quad$ Mitochondrial

$\begin{array}{ll}\text { Mitochondrial pyruvate carrier } 2 & \text { pyruvate transport } \\ & \text { Mitochondrial }\end{array}$

Mitochondrial

pyruvate transport

inner membrane

Mitochondrial 2-oxoglutarate/malate

Transport

Integral to

carrier protein

membrane

Innexin

Ion transport

$b(0,+)$-type amino acid transporter 1

Amino acid

Gap Junction

transmembrane

Integral to

transporter activity

Excitatory amino acid transporter 3

membrane

Transcritos

com baixa

expressão
Glutathione S-transferase

Uncharacterized protein

Putative serine protease K12H4.7

Regucalcin

Flexible cuticle protein 12

Chitin synthase 8

Hydroxymethylglutaryl-CoA lyase

mitochondrial sodium:dicarboxyla

te symporter

activity

Integral to

membrane

Transferase activity

Carbohydrate

binding

Serine-type

peptidase activity

Calcium ion

binding

Structural

constituent of

cuticle

Transferase

activity,

transferring hexosyl

groups

Hydroxymethylglut

aryl-CoA lyase

activity

Dos 74 genes anotados como diferencialmente expressos pelo programa Blast2GO

(consenso entre os programas DESeq2 e EdgeR), 14 foram mapeados ao KEGG,

representando 28 vias metabólicas. A via que teve mais genes representados foi a Pentose 
e Glurcuronate interconversions (três genes envolvidos), as outras vias tiveram dois ou um gene relacionado (Tabela 4).

Tabela 4: Vias metabólicas representadas na diapausa de Tetrapedia diversipes e os genes que foram relacionados com cada via.

\begin{tabular}{|c|c|}
\hline Via metabólica & Genes \\
\hline Pentose e Glurcuronate interconversions & $\begin{array}{l}\text { Lambda-crystallin homolog } \\
\text { Alcohol dehydrogenase }[N A D P(+)] A \\
\text { Aldose reductase }\end{array}$ \\
\hline $\begin{array}{l}\text { Fructose and mannose metabolism } \\
\text { Glycerolipid metabolism } \\
\text { Galactose metabolism }\end{array}$ & $\begin{array}{l}\text { Alcohol dehydrogenase }[N A D P(+)] A \\
\text { Aldose reductase }\end{array}$ \\
\hline $\begin{array}{l}\text { Drug metabolismo - cytochrome P450 } \\
\text { Arachidonic acid metabolism } \\
\text { Glutathione metabolism } \\
\text { Metabolism of xenobiotics by cytochrome P450 }\end{array}$ & Glutathione S-transferase \\
\hline $\begin{array}{l}\text { Pentose phosphate pathway } \\
\text { Caprolactam degradation }\end{array}$ & Regucalcin \\
\hline Ascorbate and aldarate metabolism & $\begin{array}{l}\text { Regucalcin } \\
\text { Inositol oxygenase }\end{array}$ \\
\hline Biosynthesis of antibiotics & $\begin{array}{l}\text { Regucalcin } \\
\text { Kynurenine/alpha-aminoadipate } \\
\text { aminotransferase, mitochondrial }\end{array}$ \\
\hline Tryptophan metabolism & $\begin{array}{l}\text { Kynurenine/alpha-aminoadipate } \\
\text { aminotransferase, mitochondrial } \\
\text { Kynurenine 3-monooxygenase }\end{array}$ \\
\hline $\begin{array}{l}\text { Lysine degradation } \\
\text { Lysine biosynthesis }\end{array}$ & $\begin{array}{l}\text { Kynurenine/alpha-aminoadipate } \\
\text { aminotransferase, mitochondrial }\end{array}$ \\
\hline $\begin{array}{l}\text { Butanoate metabolism } \\
\text { Synthesis and degradation of ketone bodies } \\
\text { Valine, leucine and isoleucine degradation } \\
\text { Geraniol degradation }\end{array}$ & Hydroxymethylglutaryl-CoA lyase \\
\hline $\begin{array}{l}\text { Purine metabolism } \\
\text { Pyrimidine metabolism } \\
\text { Nicotinate and nicotinamide metabolism }\end{array}$ & $\begin{array}{l}\text { Inosine-uridine preferring nucleoside } \\
\text { hydrolase }\end{array}$ \\
\hline $\begin{array}{l}\text { Fatty acid biosynthesis } \\
\text { Biotin metabolism }\end{array}$ & Fatty acid synthase \\
\hline Inositol phosphate metabolism & Inositol oxygenase \\
\hline Aminobenzoate degradation & Venom acid phosphatase Acph-1 \\
\hline Glycerophospholipid metabolism & $\begin{array}{l}\text { Glycerol-3-phosphate dehydrogenase 1-like } \\
\text { protein }\end{array}$ \\
\hline
\end{tabular}




\section{Discussão}

Neste trabalho foi montado o transcriptoma de larvas de $T$. diversipes utilizando indivíduos em não diapausa e em diapausa. Observando os termos do Gene Ontology verificamos que para o transcriptoma total, em relação à categoria Processos Biológicos (PB), a maioria dos genes está relacionada a processos gerais como transcription, translation, regulation of transcription, transport, signal transduction, etc. (Figura 4), refletindo de forma geral o desenvolvimento, enquanto que para o subgrupo dos genes diferencialmente expressos (DE) os termos de PB (embora poucos genes tenham sido mapeados) estão relacionados a lipids, fatty acid metabolism e cholesterol (Figura 8), termos que estão relacionados com as mudanças fisiológicas de um organismo em diapausa. Já na categoria Funções Moleculares (FM) tanto no transcriptoma geral (Figura 5) como no subgrupo de genes DE (Figura 9) os principais termos se referem à binding (ATP, metal ion, calcium, chromatin binding). Na categoria Componentes Celulares (CC) no transcriptoma total os produtos dos genes estão localizados ou são subcomponentes de algum componente celular principalmente no núcleo (Figura 6) e no subgrupo dos DE (Figura 10) eles se distribuem principalmente pelas membranas.

Em relação às vias metabólicas anotadas para os genes DE, nenhuma teve número expressivo de genes representados (Tabela 4), sendo que todos os genes mapeados a alguma via tiveram a expressão reduzida na diapausa de T. diversipes. Algumas dessas vias também foram relacionadas com a transição entre diapausa e pós-diapausa em $M$. rotundata, (Yocum et al. 2015), são elas: Glycerolipid metabolism, Pentose phosphate pathway, Ascorbate and aldarate metabolism, Tryptophan metabolism, Lysine degradation, Butanoate metabolism, Purin metabolism, Pyrimidine metabolism e Glycerophospholipid metabolism. 
No presente trabalho, poucos genes diferencialmente expressos entre larvas em não diapausa e larvas em diapausa de $T$. diversipes foram anotados (30.4\% pelo SwissProt e $45 \%$ pelo UniRef). Uma explicação para este baixo número é a dificuldade em anotar genes quando não se tem disponível o genoma de referência de um organismo próximo. Entre as abelhas, o genoma melhor anotado é o de Apis mellifera (Apini) (Elsik et al. 2014). Entretanto, o tempo de divergência entre as tribos Apini e Tetrapediini está estimado entre 80-100 ma (Ramírez et al. 2010; Cardinal et al. 2010; http://www.timetree.org/search/pairwise/Tetrapediini/Apini).

Dentre os genes aqui identificados como diferencialmente expressos, vários já foram relacionados com a diapausa em outros organismos, e alguns indicam alterações biológicas previstas como os envolvidos no metabolismo de lipídeos e no ciclo celular. Já que durante a diapausa há um queda na alimentação e o retardamento do desenvolvimento. é esperado que genes envolvidos com estes processos tenham a expressão reduzida, como observado.

Inesperadamente não foram encontrados neste trabalho genes que codificam para as proteínas heat shock (HSPs). Recentemente, Poupardin et al. (2015) comparou larvas de Chymomyza costata (Diptera) sob longo fotoperíodo (desenvolvimento direto) com larvas em curto fotoperíodo (que entrariam em diapausa) e larvas transferidas do longo para curto fotoperíodo. Neste estudo não foi encontrada uma associação clara entre os diferentes grupos amostrais e as variações nos transcritos de HSPs. Como as respostas transcricionais das HSPs ao estresse são muito dinâmicas os autores sugerem mais estudos para saber se as variações pontuais nos transcritos para estas proteínas não foi um artefato causado pela manipulação dos indivíduos (Poupardin et al. 2015). O fato de não termos encontrado transcritos para HSPs pode indicar que no momento em que as amostras foram coletadas elas não estavam submetidas a algum estresse pontual, ou que estas proteínas 
não estão envolvidas com a diapausa em $T$. diversipes, pois transcritos para HSPs foram anotados no transcriptoma total (28 transcritos). Os genes sugeridos como parte do toolkit de genes da diapausa (Poelchau et al. 2013b) também foram anotados no transcriptoma total, um transcrito para o pcna e três transcritos para o gene pepck, mas estes também não foram diferencialmente expressos na diapausa das larvas de $T$. diversipes.

Os genes que foram anotados como diferencialmente expressos foram categorizados de acordo com a função em cinco grupos: desintoxicação celular, cutícula e citoesqueleto, metabolismo de lipídeos e esteróis, ciclo celular e outros genes relacionados à diapausa.

\subsection{Desintoxicação celular}

Os genes Glutathione-S-transferase (GST) e UDP-glucuronosyltransferase 1-1 (UGT) tiveram a expressão reduzida durante a diapausa em $T$. diversipes. O gene GST também foi pouco expresso durante a diapausa da larva de Ostrinia nubilalis (Lepidoptera) (Jovanović-Galović et al. 2007) e na diapausa reprodutiva de Tetranychus urticae (Arachnida) (Bryon et al. 2013).

Em geral, as enzimas GSTs são importantes no processo de desintoxicação, adicionando glutationa aos xenobióticos ou seus derivados, estes são catalisados pelas enzimas e são impedidos de interagir com os componentes celulares (Josephy 2010). Também estão associadas à remoção de espécies reativas de oxigênio (ROS) (Bryon et al. 2013).

Em mamíferos as enzimas UGTs atuam na eliminação de compostos xenobióticos ou tóxicos endobióticos (como toxinas, drogas e carcinógenos) (McElwee et al. 2004). Estas enzimas adicionam um grupo de ácido glicurônico em diferentes moléculas lipofílicas, aumentando assim, a solubilidade destas moléculas em água (Burnell et al. 
2005). Na larva dauer (larva em diapausa de C. elegans), contrariamente ao observado em T. diversipes, o gene $U G T$ foi verificado como super expresso (McElwee et al. 2004). Esta alta expressão proporciona uma resistência ao estresse e uma vida prolongada pela eliminação da contaminação externa ou de toxinas geradas internamente (Wang \& Kim 2003). McElwee et al. (2004) propõem que a principal causa dos danos moleculares que levam ao envelhecimento é a variedade de compostos tóxicos (endobióticos e xenobióticos) presentes nos organismos, particularmente os lipofílicos, e sugere que enzimas como UGTs e GSTs envolvidas na desintoxicação são os principais mecanismos para garantir a longevidade em C. elegans. A baixa expressão do gene GST pode estar associada a não alimentação e potencial redução na ingestão de xenobióticos durante a diapausa (Jovanović-Galović et al. 2007; Bryon et al. 2013), o que também explicaria a redução na expressão de $U G T$ em $T$. diversipes.

\subsection{Cutícula e citoesqueleto}

Em T. diversipes os genes Tubulin alpha chain partial, Myosin regulatory light chain 2, Myosin light chain alkali, Actin e Actin partial foram super expressos durante a diapausa. As proteínas miosina e actina interagem para gerar a força contrátil dos músculos e as proteínas actina e tubulina fazem parte dos microtúbulos (filamentos que compõem o citoesqueleto) (Nelson et al. 2005).

Diferentes isoformas de miosina e actina foram super expressas na adaptação de larvas Cucujus clavipes puniceus (Coleoptera) ao inverno e nas larvas de verão houve super expressão de tubulina e tropomiosina o que sugere um rearranjo do citoesqueleto entre as estações (Carrasco et al. 2011). Genes que codificam para actina também foram super expressos no mosquito $C$. pipiens em diapausa em resposta a baixas temperaturas (Robich et al. 2007). Foi então sugerido que componentes do citoesqueleto podem 
contribuir para a sobrevivência destes organismos ao frio (Kim et al. 2006). Quando os microtúbulos são expostos à baixa temperatura os componentes de alpha e beta tubulina tendem a desagregar, resultando em despolimerização. Em organismos vivos a exposição ao frio pode desfazer o citoesqueleto, tornando a organização e transporte intracelular mais difícil. Para sobreviver às condições de inverno, o sistema do citoesqueleto precisa ser fortificado contra a despolimerização (Denlinger \& Michaud 2010). Considerando os dados aqui obtidos para $T$. diversipes, embora o frio não pareça ser um fator que influencie a entrada na diapausa, durante essa fase (que ocorre no inverno), podemos ter dias de baixas temperaturas (abaixo de $10^{\circ} \mathrm{C}$ no ano de coleta). Tanto a variação na temperatura quanto o inverno seco, podem ter alterado a expressão destes genes em $T$. diversipes.

Os genes Endocuticle structural glycoprotein, SgAbd-1 Flexible cuticle protein 12 e Chitin synthase 8 tiveram a expressão reduzida durante a diapausa de $T$. diversipes. Genes relacionados a proteínas da cutícula foram super expressos na larva de inverno de C. clavipes puniceus e estão relacionados a uma fortificação da cutícula (Carrasco et al. 2011). Foram também super expressos no final da diapausa na larva de Wyeomyia smithii (Diptera) (Emerson et al. 2010), na diapausa da larva farato (dentro do córion do ovo) de Ae. albopictus (Poelchau et al. 2013b) e na pupa de Helicoverpa armigera (Lepidoptera) (Zhang et al. 2013). As propriedades da cutícula nos insetos variam durante o desenvolvimento, a epiderme sintetiza três tipos de cutícula: da larva, da pupa e do adulto, sendo que as cutículas de diferentes estágios larvais são similares (Charles 2010). O que pode explicar a redução na expressão dos genes relacionados à cutícula nas larvas em diapausa de $T$. diversipes, é que há uma maior demanda de síntese de cutícula para transição de larva para pupa do que para a manutenção das larvas em diapausa, já que as larvas em não diapausa estariam seguindo o desenvolvimento para pupa e as larvas em 
diapausa não. Uma alternativa é que o fato de termos coletado pools de diferentes ínstares larvais em não diapausa, houve maior expressão de genes relacionados à cutícula nestas larvas por estarem mudando de ínstares, enquanto as larvas em diapausa estavam em um único ínstar.

\subsection{Metabolismo de lipídeos e esteróis}

A superfamília de proteína ATP binding cassette (ABC) compreende transportadores para uma variedade de compostos orgânicos e inorgânicos (Pohl et al. 2004). As $A B C$ transporters utilizam a energia da hidrólise de ATP para bombear substratos através da membrana contra um gradiente de concentração, sendo cada transportador específico a determinando substrato (Higgins 1992). ABC transporter $G$ family member 22 foi super expresso na diapausa de $T$. diversipes, alguns membros da família $\mathrm{ABCG}$ estão envolvidos no transporte de esteróis e outros em transporte de fosfolipídeos e toxinas (Pohl et al. 2004). Proteínas da família ABC transporter podem exportar moléculas tóxicas e então conceder resistência aos organismos (Wang \& Kim 2003).

Niemann-Pick tipo Cl (NPCl) e Fatty-acid synthase tiveram a expressão reduzida durante a diapausa em $T$. diversipes. Estes genes são relacionados ao metabolismo de lipídeos e esteróis. A maioria das mutações nos genes $N P C 1$ em humanos está associada com o prejuízo no tráfico celular de colesterol (Ribeiro et al. 2001). Mutações deletérias em $n p c-1$ e $n p c-2$ de C. elegans (dois homólogos ao gene NPCl de humanos) levam ao fenótipo Daf-c, que é a formação da larva dauer (em diapausa) sob condições favoráveis (Sym et al. 2000). Uma diminuição na expressão de NPC1 diminui o tráfico celular de colesterol o que resulta em uma redução da disponibilidade de substrato para DAF-9 (enzima Cytochrome P450 codificada pelo gene $d a f-9$ ) e consequentemente a não ligação 
do mesmo no receptor daf-12 que permitiria o desenvolvimento (Li et al. 2004). Estudos de genética molecular sugerem que quando hormônios (serotonina, TGFb, insulina e esteroides) estão em alta dose o crescimento reprodutivo ocorre nos nematoides, quando estão em baixa não há progressão no desenvolvimento e os nematoides formam a larva dauer em diapausa (Fielenbach \& Antebi 2008). O colesterol é precursor de esteroides, oxisteroides, ácidos biliares e vitamina $\mathrm{D}$, a falta de colesterol interfere na produção de hormônios derivados de esteróis que regulam a diapausa. A falta de colesterol induz a formação da dauer (Gerisch \& Antebi 2004).

O gene NPCla em Drosophila é necessário para a utilização eficiente e metabolismo apropriado de esteróis (Fluegel et al. 2005). Em T. diversipes o homólogo do gene $\mathrm{NPCl}$ está pouco expresso durante a diapausa, podemos relacionar a variação de expressão gênica em $T$. diversipes com as vias regulatórias da formação da larva dauer em C. elegans, este gene pouco expresso pode interferir no tráfico de colesterol e consequentemente na síntese de ecdisteroides.

O gene Acyl-CoA binding protein homolog $(A C B P)$ teve a expressão reduzida durante a diapausa em $T$. diversipes. Este gene também foi menos expresso na diapausa em $H$. armigera e ele está envolvido na regulação da biossíntese de ecdisteroides (Liu et al. 2005).

Outro gene que foi recentemente descrito como relacionado à síntese de ecdisteroides e teve a expressão reduzida durante a diapausa em T. diversipes foi o gene predito Orcokinin peptides-like isoform X1. Em B. mori as orcoquininas podem regular a síntese de ecdisteroides através da glândula protorácica, a presença destas proteínas mantem os níveis de ecdisteroides baixos (Yamanaka et al. 2011). No caso de $T$. diversipes os transcritos que codificam para este gene foram super expressos nos indivíduos em não diapausa, sabe-se que o decréscimo ou a ausência de ecdisteroides 
induz a diapausa (Denlinger 2002), isso pode explicar a alta expressão deste gene previamente à diapausa. Além da relação com ecdisteroides, o bloqueio com RNAi de duas isoformas dos genes que codificam para orcoquininas demonstrou que estas proteínas estão relacionadas com resposta ao estresse. Esse estudo, feito com besouros demonstrou que esse gene quando bloqueado levou esses insetos a exibirem mais vezes e por mais tempo o comportamento de fingimento de morte, e em larvas submersas por dois minutos em água, houve aumento significativo no tempo de despertar após o estresse (Jiang et al. 2015). Este gene também está relacionado com a percepção da luz no ciclo circadiano através dos olhos compostos em adultos de Leucophaea maderae (Blattodea) (Hofer \& Homberg 2006). Este gene é interessante para um estudo aprofundado sobre a diapausa em insetos.

O gene Fatty-acid synthase codifica uma enzima chave na conversão de açúcar em gordura na diapausa reprodutiva de C. pipiens, este gene é altamente expresso no início da diapausa e pode ser detectado durante a mesma no mosquito, ao contrário da diapausa na larva em $T$. diversipes em que o mesmo foi pouco expresso. A alta expressão deste gene no mosquito está associada a uma mudança de alimentação das fêmeas que entrarão em diapausa. Estas param de se alimentar de sangue e passam a se alimentar de fontes vegetais ricas em carboidratos, como néctar e frutas em apodrecimento. Mesmo que elas continuem se alimentado de sangue a maquinaria molecular não estará disponível para metabolizá-lo (Robich et al. 2007). Com o bloqueio dos genes Fatty acid synthase, fas-3 e fabp por RNAi em C. pipiens, as fêmeas estocaram metade da quantidade de lipídeos (Sim \& Denlinger 2009). Os adultos de $C$. pipiens continuam se alimentando durante a diapausa, portanto há uma demanda para a expressão destes genes que sintetizam lipídeos. As larvas de $T$. diversipes não se alimentam durante a diapausa, e a gordura é estocada previamente, isso explica a baixa expressão desse gene neste período. 
Após a ingestão e síntese de ácidos graxos por um organismo, estes podem ter dois destinos: comporem a reserva energética em forma de triacilglicerol ou serem utilizados em componentes fosfolipídicos das membranas. Durante o crescimento rápido de um organismo há uma demanda maior de fosfolipídios para a síntese de novas membranas, mas se o crescimento é desacelerado, a maioria dos ácidos graxos será armazenada (Nelson et al. 2005). No caso da diapausa o crescimento cessa e já foi demonstrado que triacilglicerol é a principal reserva desta fase (Hahn \& Denlinger 2011). Em tecidos animais os precursores tanto de triacilgliceróis quanto de glicerofosfolipídeos são fatty acyl-CoA (formados pela ação da acyl-coA synthethase) e L-glycerol 3-phosphate (derivado da ação de glycerol 3-phosphate dehydrogenase) (Nelson et al. 2005). Ambos Acyl-CoA synthethase e Glycerol 3-phosphate dehydrogenase tiveram a expressão reduzida durante a diapausa, o que é esperado já que não há o crescimento ativo dos indivíduos e as reservas energéticas foram previamente armazenadas quando as larvas se alimentavam.

Outro gene que teve a expressão reduzida na diapausa em $T$. diversipes e está relacionado ao transporte de lipídeos é o prominin-like, a proteína prominina está localizada nas protrusões da membrana plasmática e interage especificamente com o colesterol da membrana (Corbeil et al. 2001).

\subsection{Ciclo celular}

Os genes Rho-related BTB domain-containing protein 2 (RhoBTB2) e SAM e SH3 domain-containing protein 1 (SASH1) foram super expressos durante a diapausa de $T$. diversipes. Estes genes estão relacionados à redução na proliferação celular, crescimento e invasão em tumores (Mao et al. 2011; Martini et al. 2011), condição similar ao estado de diapausa em que o desenvolvimento cessa e a divisão celular também. Geralmente as 
células de organismos em diapausa estão paradas nas fases G0/G1 ou G2 do ciclo celular (Nakagaki et al. 1991; Tammariello \& Denlinger 1998; Koštál et al. 2009; Podrabsky \& Culpepper 2012).

A proteína RhoBTB2 pertence à subfamília RhoBTB entre as Rho GTPases (Mao et al. 2011). As Rho GTPases participam na regulação de vias ligadas à actina do citoesqueleto, na regulação da polaridade celular, transcrição gênica, na fase G1 na progressão do ciclo celular, dinâmica dos microtúbulos, vias de transporte vesicular e em uma variedade de atividades enzimáticas (Etienne-Manneville \& Hall 2002). O interesse na subfamília RhoBTB surgiu quando o gene RhoBTB2 foi identificado como homozigoticamente deletado em amostras de câncer de mama e foi proposto como gene candidato a supressão de tumores (revisto por Berthold et al. 2008). Foi demonstrado que a super expressão de RhoBTB2 inibe a proliferação de células em tumores de mama (Hamaguchi et al. 2002; Mao et al. 2011) e da tireóide (Wang et al. 2015). A proposta é que esta diminuição na proliferação esteja relacionada à diminuição da quantidade de Cyclin D1. O ciclo celular é conduzido pela ativação de cyclin-dependent kinases (CDKs), cujas atividades são orientadas por reguladores chaves como ciclinas e inibidores de CDK (CDKIs) (Yoshihara et al. 2007). Embora haja uma redução proteica de Cyclin D1, os transcritos que codificam para esta proteína não são afetados, o que sugere uma regulação pós-transcricional por RhoBTB2 (Siripurapu et al. 2005; Yoshihara et al. 2007).

$\mathrm{Na}$ diapausa do embrião de Austrofundulus limnaeus (Cyprinodontiformes) (Meller et al. 2012) foi verificado que o nível protéico de Cyclin D1 estava reduzido; nas larvas de $C$. costata destinadas a entrar em diapausa, os genes cyclins E, B e Cyclindependent kinase (CDK)1, 2 e 7 foram menos expressos (Poupardin et al. 2015); em S. crassipalpis, a proteína CDK1 estava mais fosforilada e provavelmente inativada (Pavlides et al. 2011); em H. armigera o gene CDK8 estava menos expresso no início da 
diapausa (Bao \& Xu 2011); e os transcritos para CDK2 e o grupo de proteínas $G 1 / S$ specific cyclin-e e cyclin- $k$ estavam super expressos na pós-diapausa em M. rotundata. De um modo geral, durante a diapausa de diferentes espécies estes genes estão menos expressos (Yocum et al. 2015). Nossos dados, juntamente com a quantidade proteica e o padrão de expressão de transcritos relacionados às ciclinas verificados em outros organismos, indicam que RhoBTB2 pode ser um importante regulador na parada do ciclo celular na diapausa de $T$. diversipes e possivelmente na diapausa destes outros organismos.

O transcrito SASH1 foi também super expresso durante a diapausa em $T$. diversipes. O aumento na expressão de $S A S H 1$ estimula a polimerização da actina, a adesão matriz-célula e inibe a migração celular. A redução na expressão deste gene diminui a adesão celular à matriz extracelular e está clinicamente correlacionada com a invasão e crescimento de tumores devido à redução da interação entre células do tumor e estroma facilitando o crescimento invasivo (Martini et al. 2011). Foi demonstrado em linhagens celulares de glioma que a super expressão de $S A S H 1$ reduz o crescimento e a viabilidade das células tumorais, e esta redução está relacionada com a parada do ciclo celular na fase G0/G1 (Yang et al. 2012). Assim como RhoBTB2, quando SASH1 está super expresso, a quantidade de proteínas Cyclin Dl é reduzida (Yang et al. 2012). A expressão aumentada destes dois genes pode contribuir com a parada no ciclo celular durante a diapausa em $T$. diversipes.

$\mathrm{O}$ gene predito Titin isoform $X 4$ foi super expresso durante a diapausa em $T$. diversipes e tem importância na organização e elasticidade tanto dos cromossomos quanto dos sarcômeros (Machado \& Andrew 2000). 


\subsection{Outros genes relacionados à diapausa}

O gene Cytochrome $c$ foi menos expresso durante a diapausa em $T$. diversipes. $\mathrm{O}$ aumento da expressão do gene Cytochrome $c$ está relacionado à produção de ATP, o que está associado ao desenvolvimento ativo dos indivíduos. Este gene é menos expresso na diapausa da pupa de Agrius convolvuli (Lepidoptera) (Uno et al. 2004) e com expressão ausente nas larvas de inverno de $C$. clavipes puniceus (Carrasco et al. 2011). Em $C$. pipiens, os genes Cytochrome c oxidase I e III foram super expressos durante o preparo e o fim da diapausa, permanecendo pouco expresso durante a diapausa. Este gene também foi mais expresso no início da diapausa na pupa de $H$. armigera e menos expresso durante a diapausa (Yang et al. 2010; Bao \& Xu 2011).

Em T. diversipes, os genes Venom serine protease 34 e Venom acid phosphatase Acph-1 foram menos expressos durante a diapausa. Em C. pipiens, foi notado um decréscimo na abundância dos transcritos do gene Venom allergen five nesta fase, mas não se conhece o significado funcional desta proteína durante a diapausa (Li \& Denlinger 2009).

O gene que codifica para a proteína Toll foi super expresso nas larvas de $T$. diversipes em diapausa. Esta proteína foi demonstrada como sendo um receptor transmembrana que controla o padrão dorso-ventral em embriões de Drosophila (Hashimoto et al. 1988). Além disso, mutações no gene Toll influenciam a via de sinalização de resposta imune e reduz a sobrevivência de indivíduos após uma infecção fúngica (Lemaitre et al. 1996). A análise de transcriptoma realizada em Bombus terrestris verificou que componentes da via Toll foram uniformemente expressos em todos os diferentes estágios do desenvolvimento (Colgan et al. 2011). Na diapausa os indivíduos tem o tempo de desenvolvimento mais longo, o que os torna mais suscetíveis a possíveis infecções, portanto a super expressão deste gene pode estar relacionado a mecanismos de 
defesa. Genes relacionados à imunidade também foram super expressos na diapausa em Ae. albopictus (Poelchau et al. 2013c) e em S. crassipalpis (Ragland et al. 2010), isso sugere que o alto investimento em defesa a patógenos pode ser uma estratégia comum durante a diapausa (Poelchau et al. 2013c).

GATA-binding factor $C$ teve expressão reduzida durante a diapausa em $T$. diversipes. Os fatores de transcrição GATA-binding compreendem uma família de proteínas que contém um ou dois domínios zinc finger, de ligação ao DNA, conservados. Muitos destes fatores regulam a expressão gênica ativando ou inativando genes em resposta a uma deficiência no ambiente (Lowry \& Atchley 2000).

$\mathrm{O}$ gene predito RNA binding protein fox-1 homolog 2 foi super expresso na diapausa de $T$. diversipes. A família Fox-1 das proteínas RNA-binding são conhecidas por reconhecer especificamente o elemento (U)GCAUG e regular splicing próximo a exons. (U)GCAUG é um dos elementos reguladores de splicing conservados mais distribuídos em Metazoa. Esta família de proteínas pode aumentar ou reprimir a inclusão de exons alternativos (Kuroyanagi 2009).

O gene que codifica para a proteína yellow foi super expresso durante a diapausa em T. diversipes. Este gene está relacionado com a eussocialidade em A. mellifera, especificamente com a divisão de castas. As castas operária e rainha se diferenciam no início do desenvolvimento larval, por diferença na qualidade de alimento que essas larvas recebem (Drapeau et al. 2006). Nos primeiros três dias todas as larvas se alimentam de geleia real, produto produzido pela glândula hipofaringeana de operárias jovens, mas depois desse período apenas a larva designada a se tornar rainha continua recebendo este alimento diferenciado. A geleia real é constituída principalmente por proteínas da família gênica Major Royal Jelly Protein (MRJP), esta família parece ter evoluído a partir de duplicações de um único gene primordial membro da família gênica yellow (Drapeau et 
al. 2006). Os genes da família yellow têm o padrão de expressão variável em A. mellifera: yellow-g tem expressão específica no ovário da rainha e também é expresso em estágios iniciais do embrião das operárias; yellow- $h$ é predominantemente expresso no estágio de larva no desenvolvimento da rainha, o que sugere uma função especializada para o produto deste gene; yellow-f é ativo nos estágios tardios do embrião e continua nos estágios de larva e pupa (em operárias, rainhas e machos); e yellow-e3 devido à sua alta similaridade aos genes MRJP suporta a ideia de que este gene antecede à esta família de proteínas, este é expresso na glândula hipofaringeana de operárias (nutriz, pupa e forrageiras) (Drapeau et al. 2006).

A variação na expressão deste gene (yellow) detectada para T. diversipes é de extrema importância, pois alguns trabalhos propõem uma relação entre o surgimento da divisão de castas em espécies sociais com um ancestral solitário bivoltino que entra em diapausa. Primeiramente Hunt e Amdam (2005) propuseram que o ancestral da vespa eussocial Polistes era bivoltino, com uma primeira geração com desenvolvimento e reprodução ininterruptos, e uma segunda geração que passa por diapausa na fase de prépupa ou na fase adulta e se reproduzem no ano seguinte. Considerando este ancestral, a transição do bivoltinismo para eussocialidade teria ocorrido depois que um ancestral bivoltino da segunda geração (que entrava em diapausa) dispersou em um ambiente favorável que permitiu o desenvolvimento ininterrupto, isso permitiu uma cooptação durante a evolução social para regular a determinação de castas. Observações na natureza sugerem que a nutrição durante o crescimento larval é suficiente para explicar a diferenciação de castas em Polistes (Hunt \& Amdam 2005).

Com base nesta hipótese, Fischman (2013) propôs que os mecanismos que regulam a diapausa na abelha solitária bivoltina $M$. rotundata, podem estar evolutivamente relacionados com os mecanismos que determinam castas nas abelhas 
sociais, sendo assim testou se o principal regulador da determinação de castas (nutrição larval com geleia real) também afeta a plasticidade em $M$. rotundata.

Fischman (2013) testou diferentes quantidades de alimento (coletados previamente de muitos ninhos e estocados até o momento do experimento) e testou a qualidade do alimento misturando $50 \%$ de geleia real às diferentes quantidades de aprovisionamento natural. Foi encontrado neste estudo que a quantidade e a qualidade da dieta influenciam a probabilidade da larva entrar em diapausa. Era esperado que a dieta com geleia real fosse um suplemento nutricional para as larvas, no entanto, indivíduos mantidos nesta dieta pesaram menos que os indivíduos que receberam a mesma quantidade de alimento, mas sem geleia real. Além disso, os indivíduos que tiveram esta alimentação diferenciada (com geleia real) foram mais suscetíveis a entrar em diapausa em relação às larvas mantidas com o aprovisionamento natural. Isso sugere que a geleia real pode diretamente afetar as vias que regulam a diapausa em $M$. rotundata. Foi mostrado em A. mellifera que componentes da geleia real têm atividade regulatória epigenética. A manipulação da expressão de Dna metiltransferase (Dnmt3) através de RNAi induziu a determinação de castas de maneira semelhante à indução pelo consumo de geleia real (Kucharski et al. 2008). Em larvas de $M$. rotundata que consumiram geleia real, o gene Dnmt3 foi menos expresso. Isso sugere que a evolução da determinação de castas em abelhas Apis mellifera mediada pelo consumo de geleia real envolveu a alteração de um sistema de metilação ancestral associado com a regulação da diapausa presente em abelhas solitárias (Fischman 2013).

Com base nos nossos resultados, em que muitos dos genes diferencialmente expressos encontrados estão relacionados com o metabolismo de esteróis e lipídeos, no fato que o colesterol, precursor de esteroides, regula o desenvolvimento direto ou a diapausa em C. elegans (Gerisch \& Antebi 2004), nas nossas observações em campo de 
uma variação na alimentação das larvas (aparentemente há uma variação na coloração e na compacticidade do pólen, provavelmente devido a uma maior quantidade de óleo no alimento) e nas evidências da influência nutricional da incidência da diapausa em $M$. rotundata (Fischman 2013), acreditamos que a alimentação das larvas seja o fator ambiental de maior influência nas mudanças metabólicas que induzem a diapausa envolvidas nos indivíduos de $T$. diversipes.

\section{Conclusão}

Este trabalho foi o primeiro a gerar informações sobre os mecanismos moleculares envolvidos na diapausa em $T$. diversipes, além de ser um dos poucos trabalhos em que indivíduos, de uma espécie tropical, em condições naturais foram utilizados para essa abordagem. Foi possível notar a expressão diferencial entre larvas de $T$. diversipes em não diapausa e diapausa. No entanto, poucos genes foram anotados, isso se deve à ausência de um genoma de referência de um organismo filogeneticamente próximo. Para otimizar os resultados e descrever um cenário mais completo sobre a diapausa em $T$. diversipes, um genoma de referência desta espécie será gerado em continuação a esse estudo. Um genoma de referência da mesma espécie contribuirá para melhor montagem dos transcritos e consequentemente melhor anotação dos mesmos com bancos de dados.

Os genes que foram anotados estão principalmente relacionados ao metabolismo de esteróis, lipídeos, citoesqueleto, cutícula e ciclo celular. Os genes não identificados podem ser genes novos que são interessantes não apenas para entender a diapausa, mas também os mecanismos moleculares fundamentais conservados entre diferentes grupos e assim contribuir com questões mais amplas sobre obesidade, envelhecimento e estudos farmacológicos como sugerido por Denlinger em 2008. 


\section{Referências Bibliográficas}

Alves-dos-Santos I, Melo GAR, Rozen JR JG (2002) Biology and Immature Stages of the Bee Tribe Tetrapediini (Hymenoptera: Apidae). American Museum of Natural History, 45.

Aruda AM, Baumgartner MF, Reitzel AM, Tarrant AM (2011) Heat shock protein expression during stress and diapause in the marine copepod Calanus finmarchicus. Journal of Insect Physiology, 57, 665-75.

Ashburner M, Ball CA, Blake JA et al. (2000) Gene ontology: tool for the unification of biology. Nature Genetics, 25, 25-29.

Bao B, Xu W-H (2011) Identification of gene expression changes associated with the initiation of diapause in the brain of the cotton bollworm, Helicoverpa armigera. BMC genomics, 12, 224.

Berthold J, Schenková K, Rivero F (2008) Rho GTPases of the RhoBTB subfamily and tumorigenesis. Acta Pharmacologica Sinica, 29, 285-295.

Brown CT, Howe A, Zhang Q, Pyrkosz AB, Brom TH (2012) A Reference-Free Algorithm for Computational Normalization of Shotgun Sequencing Data. , 1-18.

Bryon A, Wybouw N, Dermauw W, Tirry L, Van Leeuwen T (2013) Genome wide geneexpression analysis of facultative reproductive diapause in the two-spotted spider mite Tetranychus urticae. BMC Genomics, $\mathbf{1 4}, 815$.

Burnell AM, Houthoofd K, O'Hanlon K, Vanfleteren JR (2005) Alternate metabolism during the dauer stage of the nematode Caenorhabditis elegans. Experimental Gerontology, 40, 850-856.

Cardinal S, Straka J, Danforth BN (2010) Comprehensive phylogeny of apid bees reveals the evolutionary origins and antiquity of cleptoparasitism. Proceedings of the National Academy of Sciences of the United States of America, 107, 16207-11.

Carrasco MA, Buechler SA, Arnold RJ et al. (2011) Elucidating the Biochemical Overwintering Adaptations of Larval Cucujus clavipes puniceus, a Nonmodel Organism, via High Throughput Proteomics. Journal of Proteome Research, 10, 4634-4646.

Charles JP (2010) The regulation of expression of insect cuticle protein genes. Insect Biochemistry and Molecular Biology, 40, 205-213.

Chen B, Kayukawa T, Monteiro A, Ishikawa Y (2005) The expression of the HSP90 gene in response to winter and summer diapauses and thermal-stress in the onion maggot, Delia antiqua. Insect Molecular Biology, 14, 697-702.

Chernysh S, Kim SI, Pleskach VA et al. (2002) Antiviral and antitumor peptides from insects. Proceedings of the National Academy of Sciences of the United States of America, 99, 12628-12632. 
Ching T, Huang S, Garmire LX (2014) Power analysis and sample size estimation for RNA-Seq differential expression. RNA, 20, 1-3.

Cock PJA, Fields CJ, Goto N, Heuer ML, Rice PM (2010) The Sanger FASTQ file format for sequences with quality scores, and the Solexa/Illumina FASTQ variants. Nucleic Acids Research, 38, 1767-1771.

Colgan TJ, Carolan JC, Bridgett SJ et al. (2011) Polyphenism in social insects: insights from a transcriptome-wide analysis of gene expression in the life stages of the key pollinator, Bombus terrestris. BMC genomics, 12, 623.

Conesa A, Götz S, García-Gómez JM et al. (2005) Blast2GO: a universal tool for annotation, visualization and analysis in functional genomics research. Bioinformatics (Oxford, England), 21, 3674-6.

Corbeil D, Ro K, Fargeas CA, Joester A, Huttner WB (2001) Prominin: A Story of Cholesterol, Plasma Membrane Protrusions and Human Pathology. Traffic, 2, 8291.

Cordeiro GD (2009) Abelhas solitárias nidificantes em ninhos-armadilha em quatro áreas de Mata Atlântica do Estado de São Paulo. Universidade de São Paulo.

Denlinger DL (1986) Dormancy in tropical insects. Annual Review of Entomology, 31, 239-264.

Denlinger DL (1998) Maternal control of fly diapause. In: Maternal Effects as Adaptations (eds Mousseau TA, Fox CW), pp. 275-287. Oxford University Press, New York.

Denlinger DL (2002) Regulation of Diapause. Annual Review of Entomology, 47, 93122.

Denlinger DL (2008) Why study diapause? Entomological Research, 38, 1-9.

Denlinger DL, Armbruster P a (2014) Mosquito diapause. Annual review of entomology, 59, 73-93.

Denlinger DL, Lee K-Y (1997) A Role for Ecdysteroids in the Induction and Maintenance of the Pharate First Instar Diapause of the Gypsy Moth, Lymantria dispar. Journal of Insect Physiology, 43, 289-296.

Denlinger DL, Michaud MR (2010) Genomics, proteomics and metabolomics: Finding the other players in insect cold-tolerance. In: Low Temperature Biology of Insects (eds Denlinger DL, Lee Jr RE), pp. 91-115. Cambridge University Press, New York.

Drapeau MD, Albert S, Kucharski R, Prusko C, Maleszka R (2006) Evolution of the Yellow / Major Royal Jelly Protein family and the emergence of social behavior in honey bees. Genome Research, 16, 1385-1394. 
Drummond AJ, Ashton B, Buxton S et al. (2010) Geneious v5.1.

Elsik CG, Worley KC, Bennett AK et al. (2014) Finding the missing honey bee genes: lessons learned from a genome upgrade. BMC Genomics, 15, 86 .

Emerson KJ, Bradshaw WE, Holzapfel CM (2009) Complications of complexity: integrating environmental, genetic and hormonal control of insect diapause. Trends in genetics, 25, 217-225.

Emerson KJ, Bradshaw WE, Holzapfel CM (2010) Microarrays reveal early transcriptional events during the termination of larval diapause in natural populations of the mosquito, Wyeomyia smithii. PLoS ONE, 5.

Etienne-Manneville S, Hall A (2002) Rho GTPases in cell biology. Nature, 420, 629635.

FASTX-Toolkit (2010)

Fielenbach N, Antebi A (2008) C. elegans dauer formation and the molecular basis of plasticity. Genes \& Development, 22, 2149-65.

Fischman BJ (2013) Mechanisms involved in eusocial evolution in bees. University of Illinois.

Fluegel ML, Parker TJ, Pallanck LJ (2005) Mutations of a drosophila NPC1 gene confer sterol and ecdysone metabolic defects. Genetics Society of America, 172, 185-196.

Françoso E, Arias MC (2013) Cytochrome c oxidase I primers for corbiculate bees: DNA barcode and mini-barcode. Molecular Ecology Resources, 13, 844-850.

Fremdt H, Amendt J, Zehner R (2014) Diapause-specific gene expression in Calliphora vicina (Diptera: Calliphoridae)--a useful diagnostic tool for forensic entomology. International Journal of Legal Medicine, 128, 1001-11.

Fu L, Niu B, Zhu Z, Wu S, Li W (2012) CD-HIT : accelerated for clustering the nextgeneration sequencing data. Bioinformatics, 28, 3150-2.

García-Alcalde F, Okonechnikov K, Carbonell J et al. (2012) Qualimap: evaluating nextgeneration sequencing alignment data. Bioinformatics (Oxford, England), 28, 26789.

Gerisch B, Antebi A (2004) Hormonal signals produced by DAF-9/cytochrome P450 regulate C. elegans dauer diapause in response to environmental cues. Development (Cambridge, England), 131, 1765-76.

Gong Z-J, Wu Y-Q, Miao J et al. (2013) Global transcriptome analysis of orange wheat blossom midge, Sitodiplosis mosellana (Gehin) (Diptera: Cecidomyiidae) to identify candidate transcripts regulating diapause. PloS one, 8, e71564. 
Goto SG, Yoshida KM, Kimura MT (1998) Accumulation of Hsp70 mRNA under environmental stresses in diapausing and nondiapausing adults of Drosophila triauraria. Journal of Insect Physiology, 44, 1009-1015.

Grabherr MG, Haas BJ, Yassour M et al. (2011) Full-length transcriptome assembly from RNA-Seq data without a reference genome. Nature Biotechnology, 29, 644-652.

Hahn DA, Denlinger DL (2011) Energetics of insect diapause. Annual review of entomology, 56, 103-121.

Hamaguchi M, Meth JL, von Klitzing C et al. (2002) DBC2, a candidate for a tumor suppressor gene involved in breast cancer. Proceedings of the National Academy of Sciences of the United States of America, 99, 13647-13652.

Hansen KD, Brenner SE, Dudoit S (2010) Biases in Illumina transcriptome sequencing caused by random hexamer priming. Nucleic acids research, 38, e131.

Hashimoto C, Hudson KL, Anderson KV (1988) The Toll gene of Drosophila, required for dorsal-ventral embryonic polarity, appears to encode a transmembrane protein. Cell, 52, 269-279.

Higgins CF (1992) ABC transporters: from microorganisms to man. Annual Review of Cell Biology, 8, 67-113.

Hofer S, Homberg U (2006) Evidence for a role of orcokinin-related peptides in the circadian clock controlling locomotor activity of the cockroach Leucophaea maderae. The Journal of Experimental Biology, 209, 2794-2803.

Hunt JH, Amdam GV (2005) Bivoltinism as an antecedent to eusociality in the paper wasp genus Polistes. Science, 308, 264-267.

Jiang H, Kim HG, Park Y (2015) Alternatively spliced orcokinin isoforms and their functions in Tribolium castaneum. Insect Biochemistry and Molecular Biology, $\mathbf{6 5}$, $1-9$.

Josephy PD (2010) Genetic variations in human glutathione transferase enzymes: significance for pharmacology and toxicology. josephyHuman Genomics and Proteomics, 2010, 1-14.

Jovanović-Galović A, Blagojević DP, Grubor-Lajsić G, Worland MR, Spasić MB (2007) Antioxidant Defense in Mitochondria During Diapause and Postdiapause Development of European Corn Borer (Ostrinia nubilalis, Hubn .). Archives of Insect Biochemistry and Physiology, 64, 111-119.

Kim M, Robich RM, Rinehart JP, Denlinger DL (2006) Upregulation of two actin genes and redistribution of actin during diapause and cold stress in the northen house mosquito, Culex pipiens. Journal of Insect Physiology, 52, 1226-1233. 
Kimura KD, Tissenbaum HA, Liu Y, Ruvkun G (1997) daf-2 , an Insulin Receptor - Like Gene That Regulates Longevity and Diapause in Caenorhabditis elegans. Science, 277, 942-946.

Kostál V (2006) Eco-physiological phases of insect diapause. Journal of Isect Physiology, 52, 113-27.

Koštál V, Šimůnková P, Kobelková A, Shimada K (2009) Cell cycle arrest as a hallmark of insect diapause: Changes in gene transcription during diapause induction in the drosophilid fly, Chymomyza costata. Insect Biochemistry and Molecular Biology, 39, 875-883.

Kucharski R, Maleszka J, Foret S, Maleszka R (2008) Nutritional control of reproductive status in honeybees via DNA methylation. Science (New York, N.Y.), 319, 18271830.

Kuroyanagi H (2009) Fox-1 family of RNA-binding proteins. Cellular and Molecular Life Sciences, 66, 3895-3907.

Lander ES, Linton LM, Birren B et al. (2001) Initial sequencing and analysis of the human genome. Nature, 409, 860-921.

Langmead B, Salzberg SL (2012) Fast gapped-read alignment with Bowtie 2. Nature Methods, 9, 357-359.

Lemaitre B, Nicolas E, Michaut L, Reichhart J, Hoffmann JA (1996) The Dorsoventral Regulatory Gene Cassette Spatzle / Toll / cactus Controls the spa Potent Antifungal Response in Drosophila Adults. Cell, 86, 973-983.

Li J, Brown G, Ailion M, Lee S, Thomas JH (2004) NCR-1 and NCR-2, the C. elegans homologs of the human Niemann-Pick type $\mathrm{C} 1$ disease protein, function upstream of DAF-9 in the dauer formation pathways. Development, 131, 5741-5752.

Li A, Denlinger DL (2009) Pupal Cuticle Protein is Abundant During Early Adult Diapause in the Mosquito Culex pipiens Pupal Cuticle Protein Is Abundant During Early Adult Diapause in the Mosquito Culex pipiens. Journal of Medical Entomology, 46, 1382-1386.

Li B, Dewey CN (2011) RSEM: accurate transcript quantification from RNA-Seq data with or without a reference genome. BMC bioinformatics, 12, 323.

Liu M, Zhang T-Y, Xu W-H (2005) A cDNA encoding diazepam-binding inhibitor/acylCoA-binding protein in Helicoverpa armigera: molecular characterization and expression analysis associated with pupal diapause. Comparative Biochemistry and Physiology, Part C, 141, 168-176.

Love MI, Huber W, Anders S (2014) Moderated estimation of fold change and dispersion for RNA-seq data with DESeq2. 
Lowry JA, Atchley WR (2000) Molecular evolution of the GATA family of transcription factors: conservation within the DNA-binding domain. Journal of Molecular Evolution, 50, 103-115.

Lu M-X, Cao S-S, Du Y-Z et al. (2013) Diapause, signal and molecular characteristics of overwintering Chilo suppressalis (Insecta: Lepidoptera: Pyralidae). Scientific Reports, 3, 3211.

Machado C, Andrew DJ (2000) D-Titin: A giant protein with dual roles in chromosomes and muscles. Journal of Cell Biology, 151, 639-651.

MacRae TH (2010) Gene expression, metabolic regulation and stress tolerance during diapause. Cellular and molecular life sciences, 67, 2405-24.

Mao H, Zhang L, Yang Y et al. (2011) RhoBTB2 (DBC2) functions as tumor suppressor via inhibiting proliferation, preventing colony formation and inducing apoptosis in breast cancer cells. Gene, 486, 74-80.

Martini M, Gnann A, Scheikl D, Holzmann B, Janssen KP (2011) The candidate tumor suppressor $S A S H 1$ interacts with the actin cytoskeleton and stimulates cell-matrix adhesion. International Journal of Biochemistry and Cell Biology, 43, 1630-1640.

McElwee JJ, Schuster E, Blanc E, Thomas JH, Gems D (2004) Shared Transcriptional Signature in Caenorhabditis elegans Dauer Larvae and Long-lived daf-2 Mutants Implicates Detoxification System in Longevity Assurance. The Journal of Biological Chemistry, 279, 44533-43.

Meller CL, Meller R, Simon RP, Culpepper KM, Podrabsky JE (2012) Cell cycle arrest associated with anoxia-induced quiescence, anoxic preconditioning, and embryonic diapause in embryos of the annual killifish Austrofundulus limnaeus. Journal of Comparative Physiology B, 182, 909-920.

Meuti ME, Stone M, Ikeno T, Denlinger DL (2015) Functional circadian clock genes are essential for the overwintering diapause of the Northern house mosquito, Culex pipiens. The Journal of Experimental Biology, 218, 412-22.

Michener CD (2007) The Bees of the World. The Johns Hopkins University Press, Baltimore, Maryland.

Musacchia F, Basu S, Petrosino G, Salvemini M, Sanges R (2015) Annocript: a flexible pipeline for the annotation of transcriptomes able to identify putative long noncoding RNAs. Bioinformatics, 31, 2199-2201.

Nakagaki M, Takei R, Nagashima E, Yaginuma T (1991) Cell cycles in embryos of the silkworm, Bombyx mori: G2-arrest at diapause stage. Roux's Archives of Developmental Biology, 200, 223-229.

Nelson DL, Lehninger AL, Cox MM (2005) Lehninger principles of biochemistry. W.H. Freeman, New York. 
Pavlides SC, Pavlides SA, Tammariello SP (2011) Proteomic and phosphoproteomic profiling during diapause entrance in the flesh fly, Sarcophaga crassipalpis. Journal of Insect Physiology, 57, 635-44.

Podrabsky JE, Culpepper KM (2012) Cell cycle regulation during development and dormancy in embryos of the annual killifish Austrofundulus limnaeus. Cell Cycle, 11, 1697-1704.

Poelchau MF, Reynolds JA, Denlinger DL, Elsik CG, Armbruster PA (2011) A de novo transcriptome of the Asian tiger mosquito, Aedes albopictus, to identify candidate transcripts for diapause preparation. BMC Genomics, 12, 619.

Poelchau MF, Reynolds JA, Denlinger DL, Elsik CG, Armbruster PA (2013a) Transcriptome sequencing as a platform to elucidate molecular components of the diapause response in the Asian tiger mosquito, Aedes albopictus. Physiological Entomology, 38, 173-181.

Poelchau MF, Reynolds JA, Elsik CG, Denlinger DL, Armbruster PA (2013b) Deep sequencing reveals complex mechanisms of diapause preparation in the invasive mosquito, Aedes albopictus. Proceedings of the Royal Society B: Biological Sciences, 280, 20130143.

Poelchau MF, Reynolds JA, Elsik CG, Denlinger DL, Armbruster PA (2013c) RNA-Seq reveals early distinctions and late convergence of gene expression between diapause and quiescence in the Asian tiger mosquito, Aedes albopictus. The Journal of experimental biology, 216, 4082-90.

Pohl A, Devaux PF, Herrmann A (2004) Function of prokaryotic and eukaryotic ABC proteins in lipid transport. Biochimica et Biophysica Acta, 1733, 29-52.

Poupardin R, Schöttner K, Korbelová J et al. (2015) Early transcriptional events linked to induction of diapause revealed by RNAseq in larvae of drosophilid fly, Chymomyza costata. BMC Genomics, 16, 720.

Ragland GJ, Denlinger DL, Hahn DA (2010) Mechanisms of suspended animation are revealed by transcript profiling of diapause in the flesh fly. Proceedings of the National Academy of Sciences of the United States of America, 107, 14909-14.

Ramírez SR, Nieh JC, Quental TB et al. (2010) A molecular phylogeny of the stingless bee genus Melipona (Hymenoptera: Apidae). Molecular Phylogenetics and Evolution, 56, 519-25.

Reynolds JA, Poelchau MF, Rahman Z, Armbruster PA, Denlinger DL (2012) Transcript profiling reveals mechanisms for lipid conservation during diapause in the mosquito, Aedes albopictus. Journal of Insect Physiology, 58, 966-73.

Ribeiro I, Marcão A, Amaral O et al. (2001) Niemann-Pick type C disease: NPC1 mutations associated with severe and mild cellular cholesterol trafficking alterations. Human Genetics, 109, 24-32. 
Rinehart JP, Denlinger DL (2000) Heat-shock protein 90 is down-regulated during pupal diapause in the flesh fly, Sarcophaga crassipalpis, but remains responsive to thermal stress. Insect Molecular Biology, 9, 641-645.

Rinehart JP, Robich RM, Denlinger DL (2006) Enhanced Cold and Desiccation Tolerance in Diapausing Adults of Culex pipiens, and a Role for Hsp70 in Response to Cold Shock but Not as a Component of the Diapause Program. Journal of Medical Entomology, 43, 713-722.

Rinehart J, Yocum G, Denlinger D (2000) Developmental upregulation of inducible hsp70 transcripts, but not the cognate form, during pupal diapause in the flesh fly, Sarcophaga crassipalpis. Insect Biochemistry and Molecular Biology, 30, 515-521.

Robich RM, Rinehart JP, Kitchen LJ, Denlinger DL (2007) Diapause-specific gene expression in the northern house mosquito, Culex pipiens L., identified by supressive subtractive hybridization. Journal of Insect Physiology, 53, 235-245.

Robinson MD, McCarthy DJ, Smyth GK (2010) edgeR: a Bioconductor package for differential expression analysis of digital gene expression data. Bioinformatics (Oxford, England), 26, 139-40.

Schulz MH, Zerbino DR, Vingron M, Birney E (2012) Oases: robust de novo RNA-seq assembly across the dynamic range of expression levels. Bioinformatics (Oxford, England), 28, 1086-92.

Sim C, Denlinger DL (2008) Insulin signaling and FOXO regulate the overwintering diapause of the mosquito Culex pipiens. Proceedings of the National Academy of Sciences of the United States of America, 105, 6777-6781.

Sim C, Denlinger DL (2009) Transcription profiling and regulation of fat metabolism genes in diapausing adults of the mosquito Culex pipiens. Physiological Genomics, 39, 202-209.

Simao FA, Waterhouse RM, Ioannidis P, Kriventseva EV, Zdobnov EM (2015) BUSCO: assessing genome assembly and annotation completeness with single-copy orthologs. Bioinformatics, 1-3.

Siripurapu V, Meth J, Kobayashi N, Hamaguchi M (2005) DBC2 significantly influences cell-cycle, apoptosis, cytoskeleton and membrane-trafficking pathways. Journal of Molecular Biology, 346, 83-89.

Sym M, Basson M, Johnson C (2000) A model for Niemann-Pick type C disease in the nematode Caenorhabditis elegans. Current Biology, 10, 527-530.

Tachibana S-I, Numata H, Goto SG (2005) Gene expression of heat-shock proteins (Hsp23, Hsp70 and Hsp90) during and after larval diapause in the blow fly Lucilia sericata. Journal of Insect Physiology, 51, 641-647.

Tammariello SP, Denlinger DL (1998) G0/G1 cell cycle arrest in the brain of Sarcophaga crassipalpis during pupal diapause and the expression pattern of the cell cycle 
regulator, proliferating cell nuclear antigen. Insect Biochemistry and Molecular Biology, 28, 83-89.

Tauber MJ, Tauber CA, Masaki S (1986) Seasonal Adaptations of Insects. Oxford University Press, New York.

Uno T, Nakasuji A, Shimoda M, Aizono Y (2004) Expression of cytochrome c oxidase subunit 1 gene in the brain at an early stage in the termination of pupal diapause in the sweet potato hornworm, Agrius convolvuli. Journal of ilsect Physiology, 50, 3542 .

Vesala L, Salminen TS, Kankare M, Hoikkala A (2012) Photoperiodic regulation of cold tolerance and expression levels of regucalcin gene in Drosophila montana. Journal of Insect Physiology, 58, 704-709.

Wang J, Kim SK (2003) Global analysis of dauer gene expression in Caenorhabditis elegans. Development, 130, 1621-1634.

Wang X-P, Yang Q-S, Dalin P et al. (2012) Geographic variation in photoperiodic diapause induction and diapause intensity in Sericinus montelus (Lepidoptera: Papilionidae). Insect Science, 19, 295-302.

Wang C-J, Yang D, Luo Y-W (2015) RhoBTB2 ( DBC2 ) functions as a multifunctional tumor suppressor in thyroid cancer cells via mitochondrial apoptotic pathway. International Journal of Clinical and Experimental Medicine, 8, 5954-5958.

Wasielewski O, Wojciechowicz T, Giejdasz K, Krishnan N (2013) Overwintering strategies in the red mason solitary bee - Physiological correlates of midgut metabolic activity and turnover of nutrient reserves in females of Osmia bicornis. Apidologie, 44, 642-656.

Wolschin F, Gadau J (2009) Deciphering proteomic signatures of early diapause in Nasonia. PloS one, 4.

Xia Q-W, Chen C, Tu X-Y, Yang H-Z, Xue F-S (2012) Inheritance of photoperiodic induction of larval diapause in the Asian corn borer Ostrinia furnacalis. Physiological Entomology, 37, 185-191.

Yamanaka N, Roller L, Zitňan D et al. (2011) Bombyx orcokinins are brain-gut peptides involved in the neuronal regulation of ecdysteroidogenesis. The Journal of Comparative Neurology, 519, 238-46.

Yang L, Liu M, Gu Z et al. (2012) Overexpression of SASH1 related to the decreased invasion ability of human glioma U251 cells. Tumor Biology, 33, 2225-2263.

Yang J, Zhu J, Xu W-H (2010) Differential expression, phosphorylation of COX subunit 1 and COX activity during diapause phase in the cotton bollworm, Helicoverpa armigera. Journal of Insect Physiology, 56, 1992-1998. 
Yocum GD (2001) Differential expression of two HSP70 transcripts in response to cold shock, thermoperiod, and adult diapause in the Colorado potato beetle. Journal of Insect Physiology, 47, 1139-1145.

Yocum GD, Joplin KH, Denlinger DL (1998) Upregulation of a $23 \mathrm{kDa}$ small heat shock protein transcript during pupal diapause in the flesh fly, Sarcophaga crassipalpis. Insect Biochemistry and Molecular Biology, 28, 677-682.

Yocum GD, Kemp WP, Bosch J, Knoblett JN (2005) Temporal variation in overwintering gene expression and respiration in the solitary bee Megachile rotundata. Journal of Insect Physiology, 51, 621-629.

Yocum GD, Kemp WP, Bosch J, Knoblett JN (2006) Thermal history influences diapause development in the solitary bee Megachile rotundata. Journal of Insect Physiology, 52, 1113-20.

Yocum GD, Rinehart JP, Horvath DP et al. (2015) Key molecular processes of the diapause to post-diapause quiescence transition in the alfalfa leafcutting bee Megachile rotundata identified by comparative transcriptome analysis. Physiological Entomology, n/a-n/a.

Yoshihara T, Collado D, Hamaguchi M (2007) Cyclin D1 Down-regulation is Essential for DBC2's Tumor Suppressor Function. Biochemical and Biophysical Research Communications, 358, 1076-1079.

Zhang Q, Denlinger DL (2010) Molecular characterization of heat shock protein 90, 70 and 70 cognate cDNAs and their expression patterns during thermal stress and pupal diapause in the corn earworm. Journal of Insect Physiology, 56, 138-150.

Zhang Q, Lu Y-X, Xu W-H (2013) Proteomic and metabolomic profiles of larval hemolymph associated with diapause in the cotton bollworm, Helicoverpa armigera. BMC genomics, 14, 751.

Zhbannikov IY (2013) SeqYclean. 


\section{APÊNDICE A - Comparações entre as montagens}

As comparações entre o Trinity (Grabherr et al. 2011) e o Velvet/Oases (Schulz et al. 2012) foram feitas usando três transcriptomas de larvas (Diapausa1, Diapausa2 e Diapausa3 da Tabela 1), pois não houve capacidade computacional para fazer uma montagem conjunta usando todos os transcriptomas e diferentes valores de $k$-mer no Velvet/Oases (mesmo com a normalização digital prévia). Foi comparada a montagem com o valor único de $k$-mer $=25$ e também a opção de vários valores de $k$-mers (merged) do Velvet/Oases (Tabela A1).

Tabela A1: Comparação entre os programas de montagem de novo Trinity e Velvet/Oases.

\begin{tabular}{llll}
\hline & Trinity & Velvet/Oases(25) & Velvet/Oases(merged, 19-35) \\
\hline $\begin{array}{l}\text { Tamanho do transcriptoma } \\
\text { montado (bp) }\end{array}$ & 97.512 .084 & 156.628 .614 & 914.456 .788 \\
\hline Número de reads & 152.836 .280 & 152.836 .280 & 152.836 .280 \\
\hline Reads mapeadas & $148.011 .236(96.84 \%)$ & $152.053 .262(99.49 \%)$ & $152.214 .501(99.59 \%)$ \\
Reads não mapeadas & $4.825 .044(3.16 \%)$ & $783.018(0.51 \%)$ & $621779(0.41 \%)$ \\
Cobertura média & 144.14 & 92.62 & 15.96 \\
Número total de contigs & 75.769 & 76.879 & 347.688 \\
\hline
\end{tabular}

Nas comparações entre os programas Velvet/Oases e o Trinity, o programa Trinity foi escolhido por apresentar menor número de contigs final, com uma maior cobertura média, mas principalmente por requerer menor demanda de tempo para fazer a montagem. Com o programa Trinity foram realizadas várias montagens a partir de conjuntos de dados diferentes: com todos os transcriptomas de T. diversipes gerados em nosso laboratório (nove de larvas e seis de adultos, com os dados normalizados) usando como base a referência de Apis mellifera (Trinity 1); com todos os transcriptomas (larvas e adultos, dados normalizados) sem referência (Trinity 2); com todos os transcriptomas de larvas (dados normalizados) (Trinity 3); e com cada transcriptoma de larva separadamente e sem normalização (Trinity 4). Para o último as montagens foram 
agrupadas em um único arquivo e as sequências com $95 \%$ de similaridade foram consideradas iguais com o programa CD-HIT-EST (Fu et al. 2012).

Entre as comparações (Tabela A2), consideramos a melhor montagem aquela que gerou o menor número de contigs e que em análise subsequente resultou no maior número de reads alinhadas a esse transcriptoma, pois quanto mais reads alinhadas melhor a montagem. Considerando essa premissa, a montagem Trinity 4 foi escolhida. As estatísticas foram visualizadas no programa Qualimap (García-Alcalde et al. 2012) e com o script do Trinity (TrinityStats.pl).

Tabela A2: Comparação entre diferentes formas de montagem com o programa Trinity.

\begin{tabular}{|c|c|c|c|c|}
\hline & Trinity 1 & Trinity 2 & Trinity 3 & Trinity 4 \\
\hline $\begin{array}{l}\text { Tamanho do transcriptoma } \\
\text { montado (bp) }\end{array}$ & 6.059 .995 & 131.639 .563 & 103.746 .958 & 398.796 .751 \\
\hline Número de reads & 390.445 .850 & 390.445 .850 & 232.268 .572 & 232.268 .572 \\
\hline $\begin{array}{l}\text { Taxa média de } \\
\text { alinhamento }\end{array}$ & $13.26 \%$ & $94.09 \%$ & $94.86 \%$ & $99.59 \%$ \\
\hline $\begin{array}{l}\text { Número total de } \\
\text { transcritos }\end{array}$ & 17.218 & 129.509 & 95.470 & 379.077 \\
\hline Número de genes & 14.708 & 93.063 & 67.351 & 42.902 \\
\hline Tamanho médio dos genes & 280 & 345 & 357 & 1047 \\
\hline
\end{tabular}

Legenda: Trinity 1: montagem de novo usando todos os transcriptomas e o genoma de A. mellifera como base; Trinity 2 : montagem de novo usando todos os transcriptomas (larvas e adultos); Trinity 3: montagem de novo usando todos os transcriptomas de larvas; e Trinity 4: montagem de novo de cada transcriptoma de larva separadamente.

Após a anotação dos genes e visualização do alinhamento das reads aos transcritos no programa Geneious (Drummond et al. 2010), foi observado que em partes de alguns transcritos, geralmente na posição mais central, não havia uma cobertura consistente de reads comparado ao restante da sequência. Diante esta situação, mudamos alguns parâmetros do Trinity e fizemos mais testes. Os parâmetros finais escolhidos foram: 
\$./Trinity --seqType fq --max_memory 50G --CPU 10 --left All_larvae_PE1.fastq --right All_larvae_PE2.fastq --bypass_java_version_check --normalize_reads --min_kmer_cov 10 --min_glue 30 --output All_larvae_T4_new_version_trinity

Usamos Trinity 3 e Trinity 4 da montagem anterior para comparar com a nova montagem (Trinity 5) e refizemos os mesmos parâmetros com a versão atualizada do Trinity-2.0.6 (Trinity 6). Além do menor número de contigs e maior alinhamento das reads ao transcriptoma, foram consideradas também as análises no programa BUSCO (Simao et al. 2015) para a escolha da melhor montagem (Trinity6). O programa BUSCO utiliza 2675 genes ortólogos em artrópodes como referência. Sendo assim, cada transcriptoma foi triado quanto à presença destes genes em estado completo, se duplicados, fragmentados ou ausentes. Para rodar o BUSCO os nomes das sequências do Trinity foram alteradas para um sequência numérica usando o comando:

\$ awk '/^>/\{print ">" ++i; next $\}\{\text { print }\}^{\prime}<$ Montagem.fasta $>$ Montagem_num.fasta

E para rodar o BUSCO o seguinte comando foi utilizado:

\$ python BUSCO_v1.1b1.py -o Resultados_busco -in Montagem_num.fasta -1 arthropoda $-\mathrm{m}$ trans 
Os resultados das comparações podem ser visualizadas na tabela A3.

Tabela A3: Comparação entre as diferentes montagens com o programa Trinity.

\begin{tabular}{lllll} 
& Trinity $\mathbf{3}$ & Trinity $\mathbf{4}$ & Trinity $\mathbf{5}$ & Trinity 6 \\
\hline Número total de transcritos & 95.470 & 379.077 & 30.180 & 29.320 \\
\hline Número de genes & 67.351 & 42.902 & 30.084 & 29.298 \\
\hline Número de reads alinhadas & 232.268 .572 & 232.268 .572 & 232.268 .572 & 232.268 .572 \\
\hline Taxa média de alinhamento & $94.86 \%$ & $99.59 \%$ & 98.79 & 98.73 \\
\hline Tamanho médio dos genes & 357 & 1.047 & 534 & 580 \\
N50 & 2.345 & 2.030 & 1.809 & 1.781 \\
BUSCO (Total 2675 genes) & & & & \\
Genes completos & 821 & 838 & 2.073 & 2.063 \\
Genes completos duplicados & 1.479 & 1.589 & 99 & 110 \\
Genes fragmentados & 166 & 100 & 140 & 141 \\
Genes ausentes & 209 & 148 & 363 & 361 \\
\hline
\end{tabular}

Legenda: Trinity 3: montagem de novo usando todos os transcriptomas de larvas; Trinity 4: montagem de novo de cada transcriptoma de larva separadamente; Trinity 5: montagem de novo, com diferentes parâmetros, usando todos os transcriptomas de larvas; Trinity 6: mesma montagem que Trinity 5 usando a versão mais recente do Trinity (Trinity2.0.6).

\section{APÊNDICE B - Pipeline da análise dos dados}

\# Visualização da qualidade do sequenciamento no FASTQC

\# Limpeza das 14 primeiras bases de todas as reads para evitar o desvio GC encontrado na montagem da biblioteca da plataforma Illumina

\$ fastx_trimmmer -f 14 -i File1_PE1.fastq -o File1_PE1_GC_cleaned.fastq

\# Limpeza das reads por qualidade e tamanho

\$./seqyclean -qual 3030 -minimum_read_length 31 -1 File1_PE1_GC_cleaned.fastq -2

File1_PE2_GC_cleaned.fastq -o File1_cleaned.fastq 
\# Juntar as reads limpas em um único arquivo

\$ cat Diapausa1_cleaned_PE1.fastq Diapausa2_cleaned_PE1.fastq

Diapausa3_cleaned_PE1.fastq Larvas1_PE1_cleaned.fastq Larvas2_PE1_cleaned.fastq Larvas3_PE1_cleaned.fastq Larvas4_PE1_cleaned.fastq Larvas5_PE1_cleaned.fastq Larvas6_PE1_cleaned.fastq > All_larvae_PE1.fastq

\# Exportar o path da pasta do bowtie2

\$export PATH=\$PATH:/media/lgea/pkfs/bowtie2-2.2.5/

\# Montagem de novo usando Trinity-2.0.6 (incluindo normalização digital)

\$./Trinity --seqType fq --max_memory 50G --CPU 10 --left All_larvae_PE1.fastq --right All_larvae_PE2.fastq --bypass_java_version_check --normalize_reads --min_kmer_cov 10 --min_glue 30 --output All_larvae_T4_new_version_trinity

\#Exportar o path do samtools e RSEM

\$ export PATH=\$PATH:/media/lgea/pkfs/samtools-1.2/

\$ export PATH=\$PATH:/media/lgea/pkfs/rsem-1.2.22/

\# Alinhamento das reads ao transcriptoma montado (roda para cada grupo de reads limpas)

\$ ./align_and_estimate_abundance.pl --transcripts All_larvae_T4_new_version_trinity -seqType fq --left Diapausa1_cleaned_PE1.fastq --right Diapausa1_cleaned_PE2.fastq -est_method RSEM --aln_method bowtie2 --trinity_mode --prep_reference --output_dir diapausa1_NT4_RSEM 
\# Análise de expressão diferencial (DE) usando EdgeR e DESeq2 (inclusos no Trinity)

\# Gerar a matriz com a contagem das reads pelo RSEM

\$ perl abundance_estimates_to_matrix.pl --est_method RSEM --out_prefix Trinity_new_T4 RSEM.genes_D1_NT4.results $\quad$ RSEM.genes_D2_NT4.results RSEM.genes_D3_NT4.results RSEM.genes_L1_NT4.results

RSEM.genes_L2_NT4.results RSEM.genes_L3_NT4.results RSEM.genes_L4_NT4.results RSEM.genes_L5_NT4.results

\# No ambiente R instalar os pacotes necessários para análises de DE

$\mathrm{R}$

source("http://bioconductor.org/biocLite.R")

library(cluster)

source("http://bioconductor.org/biocLite.R")

biocLite("Biobase")

source("http://bioconductor.org/biocLite.R")

biocLite("qvalue")

biocLite("edgeR")

$\mathrm{q}()$

\# DE EdgeR (Trinity)

\$ perl run_DE_analysis.pl --matrix Trinity_new_T4.counts.matrix --method edgeR -samples_file samples_described.txt 
\$ perl ../analyze_diff_expr.pl --matrix ../Trinity_new_T4.TMM.fpkm.matrix -P 1e-3 -C 2 --samples ../samples_described.txt

\#DE DESeq2 (Trinity)

$\mathrm{R}$

source("http://bioconductor.org/biocLite.R")

biocLite("DESeq2")

$\mathrm{q}()$

\$ perl run_DE_analysis.pl --matrix Trinity_new_T4.counts.matrix --method DESeq2 -samples_file samples_described.txt

\$ perl analyze_diff_expr.pl --matrix Trinity_new_T4.TMM.fpkm.matrix -P 1e-3 -C 2 -samples samples_described.txt

\# Comparar a matriz do EdgeR com a matriz do DESeq2 e selecionar os transcritos comuns (script disponível em https://github.com/nat2bee/fasta-manipulation)

\$ python compare_DE_nat2bee.py -1 diffExpr.P1e-3_C2_edgeR.matrix -2 diffExpr.P1e-

3_C2_deseq2.matrix -o Trinity_new_T4_consenso

\# Seleciona os transcritos de um arquivo fasta baseado na lista de Ids do consenso entre EdgeR e DESeq2 (script disponível em https://github.com/nat2bee/fasta-manipulation)

\$ python Chomper_genes.py $-\mathrm{i} \quad$-f $\quad$ Trinity_new_T4_without_bowtie.fasta $\quad-1$ Trinity_new_T4_consenso-common.txt -o Trinity_new_T4 